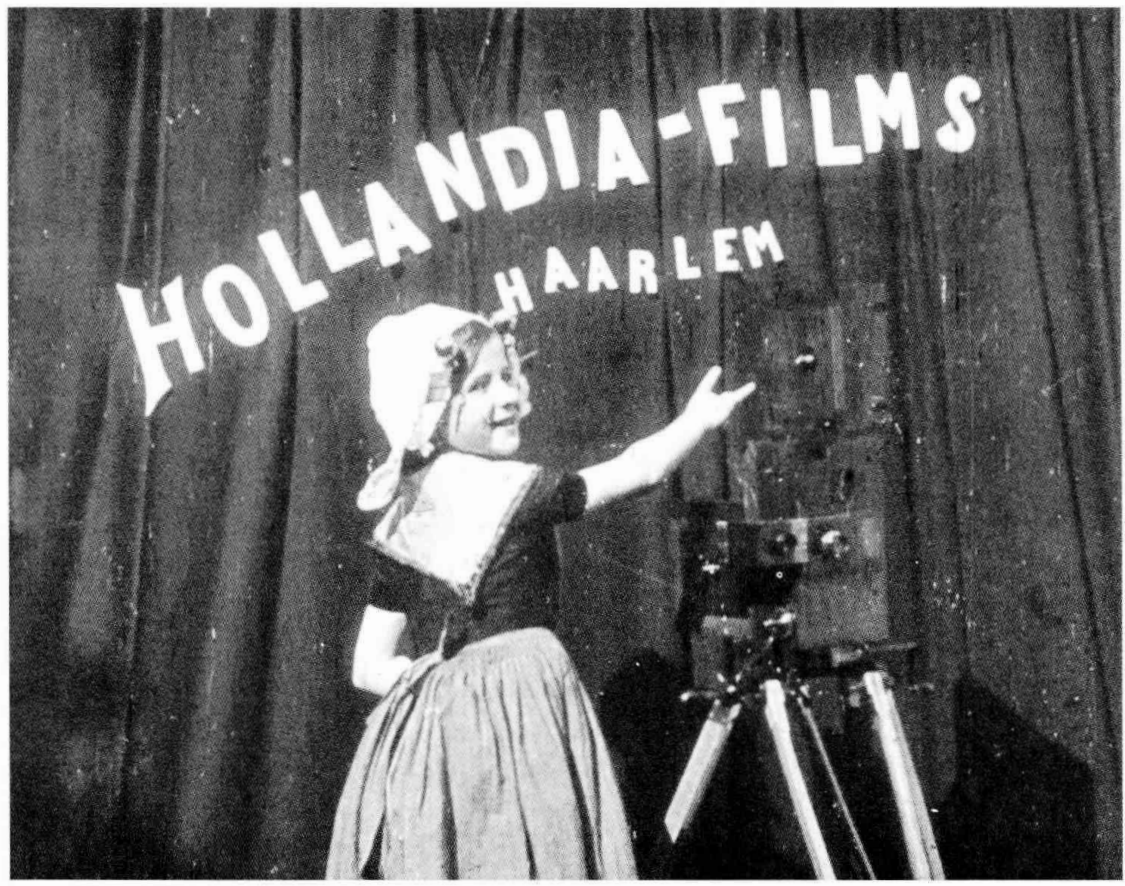




\section{Enrigue Guerra Manzo}

Doctor en Ciencias Sociales con especialidad en Sociología por El Colegio de México. Investigador de la Universidad Autónoma Metropolitana-Xochimilco. Actualmente trabaja en el proyecto Integrados y Marginados: los Juegos de Poder Local en la Formación del Estado Posrevolucionario, 1910-1950. Sus principales trabajos han sido sobre historia política, entre los que cabe destacar: Caciquismo y orden público en Micboacán, 1920-1940, Col.mex, México, 2002; "Guerra cristera y orden público en Coalcomán, Michoacán (19271932)", Historia Mexicana, vol. Ll, núm. 2, 2001; "Los pueblos indígenas: entre la comunidad corporativa y el pluralismo, 1968-2001" en Lorenzo Meyer e Ilán Bizberg (coords.), Una Historia contemporánut de México, 1968-2000, Océano, México, 2004.

\section{Resumen}

El presente ensayo pasa revista a los principales exponentes de cada una de las tres generaciones de estudiosos de la revolución mexicana de 1910 que se han sucedido en el siglo xx, y presta especial atención a los horizontes de interpretación sobre los que han colocado a ésta y a sus resultados. Su argumento central es que si hoy queremos superar el empantanamiento en que ha caído la literatura revisionista, la última de las tres generaciones, no sólo debemos precisar los mapas del debate, sino también reparar en la necesidad de combinar una doble perspectiva metodológica, la del compromiso (posición asumida por las dos primeras generaciones) y el distanciamiento (postura central del revisionismo).

\section{Palabras clave:}

Revolución mexicana, Estado posrevolucionario, escuelas de interpretación, literatura revisionista, historia política.

\section{Abstract}

This essay reviews the main exponents of each of the three generations of the Mexican revolution of 1910 scholars that emerged in the 20th century, paying particular attention to the horizons of interpretation on which they placed the revolution and its results. Its main argument is that if one wishes to break the stalemate reached by revisionist literature, the last of the three generations, it is essential not only to determine the maps of the debate but also to realize the need for a dual methodological perspective, combining commitment (the position assumed by the first two generations) and distancing (the central position of revisionism).

\section{Key words:}

Mexican revolution, post-revolutionary State, schools of interpretation, revisionist literature, political history.

Fecha de recepción: enero de 2005

Fecha de aceptación: junio de 2005 


\title{
Pensar la revolución mexicana: tres horizontes de interpretación
}

\author{
Enrique Guerra Manzo
}

$\mathrm{L}$ a historia política ${ }^{1}$ no sólo tiene una larga tradición en nuestro país sino que es uno de los géneros que más han sido cultivados por la historiografía. ${ }^{2}$ Siempre ha habido entre los estudiosos una fascinación por el poder. ${ }^{3}$ De ahí que no sea casual que al acontecimiento sociopolítico más importante del siglo Xx, la revolución de 1910, se le haya dedicado la mayor atención que a cualquier otro fenómeno de nuestra historia desde la independencia. Ya en los años sesenta los estudiosos empezaron a quejarse de lo difícil que era estar al día sobre el tema ante la

${ }^{1}$ Dado que el término política es polisémico y no está exento de debates, aquí se entenderá por él, en un sentido operacional más que de rigurosidad conceptual, la "relación de poder entre el Estado y los diferentes actores que componen la sociedad civil", ya sea en su carácter individual o colectivo, según el caso. Véanse Meyer, "Periodización", 1979, p. 184, y Portantiero, Productión, 1988, p. 118. Una explicación teórica más amplia aparece en Sartori, Elementos, 1999. pp. 233-256.

2 Potash, "Historiografía", 1961, p. 384, y Medina, "Historia", 1998, p. 298.

${ }^{3}$ Potash, "Historiografía", 1961, p. 377; González, Ronda, 1997, p. 234, y "Quehacer", 1998, p. 269; Florescano, "Minucias", 1978, p. 23; Hoyo, "Historiografía", 1979, pp. 234-237; Meyer, "Periodización", 1979, p. 184, y Womack, "Mexican", 1971 , p. 478. proliferación de libros, artículos y tesis que aparecían en México, Estados Unidos y media docena más de países. Pero en las tres décadas siguientes esta proliferación bibliográfica, que sería bautizada como historiografía revisionista, ${ }^{4}$ se haría aún más apabullante. ${ }^{5}$

${ }^{1}$ En una nota al artículo de Bailey, "Revisionismo", 1979, Antonio Saborit afirma que el término parece haber surgido por primera vez en 1973, en el prólogo a la edición española de la obra de Jean Meyer, Ia revolución mexicana, 1910-1940. El propio Bailey, "Revisionismo", 1979, p. Il, afirma que el término surgió a principios de la década de 1970 para calificar a la historiografía que atacaba las interpretaciones oficiales de la revolución mexicana que imperaron hasta los años sesenta. Sin embargo, ha sido Knight, "Interpretaciones", 1989 , p. 23 , quien ha definiclo al revisionismo con mayor precisión: se trata de "las nuevas corrientes de interpretación histórica [... que han avanzado en contraposición a la vieja ortodoxia. No tiene nada que ver con el 'revisionismo' marxista. Además [no todas las historias recientes son] revisionistas: muchas no tienen un enfoque interpretativo claro, otras son más bien 'tradicionales' u ortodoxas". Véase también Salmerón y Serrano, "Auge", 2003, p. 192.

'Sobre las quejas en los sesenta véase Potash, "Historiografía", 1961, p. 386; Womack, "Mexican", 1971, p. 480; y para las décadas siguientes Bailey, "Historiografía”, 1979, González, "Quehacer", 1998, p. 269 y Ronda, 1997 , p. 237 ; Florescano, Nuevo, 1999, pp. 72 y ss.; Carr, "Recent", 1980, p. 11. Un 
Existen numerosos balances sobre la literatura de la revolución mexicana y sus criterios para clasificarla varían por generaciones de estudiosos, ${ }^{6}$ por escuelas de interpretación, ${ }^{7}$ por perspectivas metodológicas empleadas 8 y por disciplinas y líneas ideológicas de los autores. ${ }^{9}$ En esta ensalada de criterios no faltan los autores posmodernos que proponen como hilo central "las diferentes formas de representar la temporalidad". ${ }^{10}$

En mi opinión, una de las aproximaciones más heurísticas es combinar dos criterios que hasta ahora se han mantenido separados: el generacional y el de las filiaciones teóricas de cada autor. Esta forma de proceder tiene las siguientes virtudes: primero, es posible observar con mayor claridad cuáles han sido los temas, problemas y proyecciones valorativas que han marcado a cada una de las rondas de estudiosos; segundo, permite dilucidar cuáles han sido los modelos o escuelas de interpretación que han coexistido tanto en el interior de cada generación como de manera transgeneracional. ${ }^{1.1}$

buen balance de los estudios dedicados a la revolución mexicana en Japón y Europa es el de Raat, "Revolución", 1983.

${ }^{6}$ Knight, "Interpretaciones", 1989.

7 Mature, "Orígenes", 2000, y “Actores", 1989.

${ }^{8}$ Aquí están, por ejemplo, los partidarios de la dicotomía centro-periferia, o los debates entre positivistas e historicistas. Al respecto, véase Matute, "Historia", 1999, y "Orígenes", 2000; Héau y Rajchenberg, "Leyenda", 1992; Salmerón y Serrano, "Auge", 2003, y Serrano, "Historiografía", 2000.

9 Nava, "Apuntes", 1986; Loaeza, "Cambio", 1990, y Medina, "Historia", 1998.

${ }^{10}$ Rico, Pasado, 2000, pp. 123-124.

${ }^{11}$ Los términos escuela o corriente historiográfica se entenderán como sinónimos de lo que Thomas Kuhn ha definido como paradigma: "una teoría cientí-
Dado que nuestro tema central son las interpretaciones de la revolución mexicana, aquí se excluye a los autores que se inclinaron más por escribir un relato de la misma que por aventurar una explicación. Este artículo no pretende ser sólo un recuento más -si bien ello es inevitable- de los debates historiográficos de las tres principales generaciones de estudiosos que se sucedieron en el siglo $\mathrm{xx},{ }^{12}$ sino contribuir a animar la polémica sobre una tarea aún pendiente en nuestro medio académico: alcanzar una mejor explicación de la naturaleza de la lucha armada de 1910 y de sus resultados. Su principal argumento es que el núcleo del debate historiográfico en la pasada centuria giró en torno al problema de las continuidades y discontinuidades entre el antiguo y el nuevo régimen: las primeras dos generaciones subrayan la ruptura, mientras que la tercera pone el acento en las continuidades. $\mathrm{Si}$ hoy queremos superar el empantanamiento en que ha caído la literatura revisionista, no sólo debemos precisar los mapas del debate sino también reparar en la necesi-

fica junto con un ejemplo de alguna aplicación triunfal y sorprendente". Con esta última palabra se quiere aludir a que el éxito de una teoría o de una investigación ejemplar sean lo bastante impresionantes como para que los científicos se sientan movidos a tratar de imitar ese triunfo "buscando otras explicaciones, predicciones, o lo que sea, en el mismo modelo". Véanse Kuhn, Estructura, 1990, p. 269; Putnam, "Corroboración", 1985, pp. 133-134.

${ }^{12}$ En realidad es posible observar en las postrimerías de ese siglo a una cuarta escuela, la "culturalista" o "nueva historia cultural", pero dado que su programa de investigación aún está en ciernes, es preferible dejarla fuera, pues de lograr consolidarse será una escuela del siglo XxI. Sobre las aporías de esta nueva corriente historiográfica, véanse Knight, "Subalterns", 2002, y Barrón, Historias, 2004. 
dad de combinar una doble perspectiva metodológica, la del compromiso (posición asumida por las dos primeras generaciones) y el distanciamiento (postura central del revisionismo). ${ }^{13}$

\section{EL PROBLEMA DE LA PRIMERA GENERACIÓN: NATURALEZA DE LA REVOLUCIÓN Y RECONSTRUCCIÓN DEL NUEVO RÉGIMEN}

En este apartado se exploran las ideas de los autores que escriben en un momento en que aún estaban frescas en la memoria colectiva las batallas de la revolución y en el que sus protagonistas andaban en busca de caminos para institucionalizar a esta última. ${ }^{14}$ Reflexionan en un contexto en el que emerge un nuevo sistema de acción

${ }^{13}$ La mejor explicación de esta postura metodológica la ha dado Norbert Elias: por distanciamiento entiende un menor compromiso emocional con lo que se observa, es decir, mayor objetividad, en cambio, con el término compromiso alude a un alto grado de simpatía emocional con el objeto de estudio (predominio de la subjetividad). Para Elias el mayor problema de los científicos sociales es, ¿cómo mantener separadas las funciones de observador (distanciamiento) y la de participante (compromiso)?, y ¿cómo lograr que impere su función de observador? Considera que en el grado de desarrollo en que se encuentran las ciencias sociales los científicos no pueden dejar de tomar partido en los "asuntos políticos y sociales de su grupo y su época, ni pueden evitar que éstos les afecten". Además su participación personal, "su compromiso, constituyen una de las condiciones previas para comprender el problema que han de resolver". Empero, agrega, esta posición debe ser complementada con la actitud del distanciamiento, "mirar desde fuera del río de la historia". Para una aproximación más amplia de estos problemas, véase Elias, Compromiso, 1990, pp. 1-28.

${ }^{14}$ Skocpol, Estados, 1984, ha mostrado que una revolución no sólo es la destrucción del antiguo régimen sino también la construcción de uno nuevo. histórica ${ }^{1.5}$ marcado por el ascenso de las masas y su entrada en la política, esfera que les estaba vedada en el antiguo régimen. ${ }^{16}$ Para los autores de la primera generación, la lucha armada de 1910 se manifestó, entre otras cosas, como un remolino que arrancó a los hombres de sus lugares de origen y los trasladó a recónditos lugares, obligándolos a descubrir y abrirse ante otros compatriotas, unos por convicción, combatiendo en las diferentes facciones revolucionarias o el ejército federal, otros huyendo de "la bola". Ramón Beteta afirmó en los años treinta que "con

${ }^{15}$ En polémica con estudiosos de la revolución francesa que confunden a ésta con sus causas, Furet, Pensar, 1980, pp. 36-37, ha desarrollado este concepto para referir "la aparición en la escena de la historia de una modalidad práctica e ideológica de la acción social que no se inscribe en nada de lo que precedió; un tipo de crisis la hace posible, pero no necesaria; y la revuelta no le ofrece ningún modelo puesto que por definición forma parte del antiguo sistema político y cultural".

${ }^{16}$ Considero que los autores de la primera generación percibían más el nuevo sistema de acción histórica que irrumpía en la palestra pública -y en ese sentido se aproximaban al punto de vista de Augustin Cochin- que los seguidores revisionistas del Tocculeville observador de las continuidades. Furet ha mostrado que aunque al final de su vida Tocqueville se preocupó por el problema de las discontinuidades, dejó inconclusa esa tarea. Por ello considera imprescindible complementar sus ideas con las de Cochin, agudo observador del problema de la ruptura y la emergencia de una nueva sociabilidad política "que sólo espera la ocasión para ocupar toda la escena, en esto consiste el descubrimiento de Augustin Cochin". Ibid., pp. 26-29 y 54 y ss. Entre los escasos autores que se han dado cuenta de este sesgo del revisionismo están Florescano, Nuevo, 1999; Guerra, "Teoría", 1989 y México, 1991; Knight, "Revolución", 1986 y Revolución, 1996. Todos ellos -salvo Knight-seguidores de Furet. 
la revolución -nuestra fuerza principalnos descubrimos; al analizar la revolución hemos entendido nuestra heterogeneidad y falta de unidad". ${ }^{17}$

De este modo, los grandes problemas nacionales durante la fase de reconstrucción del nuevo régimen (1916-1940), dicho de manera muy sintética, fueron los siguientes: integración nacional, edificar un nuevo Estado, lo que implicaba, entre otras cosas, domesticar al ejército, crear una infraestructura institucional que abriera paso a la participación de las masas en la política, y, puesto que la revolución vino del campo a las ciudades, definir la cuestión agraria (haciendas o ejidos). Éstos no fueron los únicos problemas que se manifestaron en el proceso político abierto en 1910, pero sí los que más llamaron la atención de los primeros pensadores de la lucha armada, mismos que se empeñaron en comprenderlos y, en ocasiones, ofrecerles alguna solución.

Así, uno de los primeros desafíos para las elites gobernantes del nuevo régimen fue el de cómo construir una nación homogénea y unida, lo cual implicaba, entre otras cosas, triunfar ahí donde habían fracasado los liberales del siglo XIX: la transformación del indio en ciudadano, aspecto en el que desde 1916 las ideas del antropólogo Manuel Gamio fueron muy importantes.

Gamio influyó decisivamente en la política indigenista de los gobiernos que se sucedieron a partir de 1920, especialmente con su obra clásica Forjando patria de 1916, cuyas ideas se empeñó en mantener y desarrollar hasta los años treinta. En sus

17 Citado en Benjamín, "Revolución", 1996, p. 431. Véase también, Beteta, "Aspectos", 1950, pp. 205-214. amplios estudios antropológicos y etnológicos Gamio descubrió que el fracaso en la incorporación del indio se debía a dos razones: primero, la resistencia de las etnias a una cultura de raigambre europea que sentían ajena; segundo, a nuestra ignorancia sobre cómo pensaban los indios. ${ }^{18}$ Desde Sahagún, como ha observado Brading, no se había intentando emprender una empresa antropológica como la de Gamio. Si el Estado quería apoderarse del alma de los indios y arrebatárselos a la Iglesia, había que conocerlos mejor, sólo así se encontrarían los caminos para su ulterior incorporación. ${ }^{19}$

La población de México, según Gamio, estaba formada desde la colonia por tres tipos de razas: descendientes de europeos, mestizos e indígenas. ${ }^{20}$ Estos últimos habían sido siempre los parias, desheredados y oprimidos, pero la revolución de 1910 les ha dicho que "abandonen su letargo y comiencen a vivir". La revolución -argumenta- es la lucha de dos razas: los mestizos del norte y los indígenas del sur. Pero son los del norte los que triunfaron. Ello se debe a que los indios se han estacionado intelectualmente, tienen escasa preparación para dirigir revoluciones triunfantes. Pero la raza mestiza, la eterna rebelde y directora de las luchas contra la clase de sangre pura o extranjera, es la que mejor

${ }^{18}$ Gamio, Forjando, 1992, pp. 5-13, 23-26.

19 Véase Brading, "Manuel", 1989. Más tarde Calles en su famoso grito de Guadalajara ampliaría esta cruzada para "salvar a la niñez" de las garras de la Iglesia. Véase sobre este último punto Torres, Edtucación, 1997, p. 126.

${ }^{20}$ De hecho, la "cuestión racial" atraviesa la obra de la mayoría de los escritores de la primera generación y desaparece en las siguientes generaciones, salvo en algunos casos, como el de Hansen, Política, 1971. 
ha comprendido los "lamentos muy justos de la clase indígena y aprovechado sus poderosas energías latentes, las cuales usó siempre como palanca para contener las opresiones del poder". ${ }^{21}$

Gamio llega a la conclusión de que sólo si se diseñan políticas específicas a cada etnia y región, y no mediante una política nacional uniforme, es posible encontrar el modo de incorporar al indio a la nación y forjar una patria homogénea fincada en el mestizaje cultural. Afirmaba que si los indígenas aparecían como bárbaros y atrasados ello se debía a que se los ha mantenido en esa condición por la fuer$\mathrm{za}$, se los ha relegado al olvido. Para propiciar un cambio en sus condiciones materiales y sociales de vida apoyaba la idea de Andrés Molina Enríquez ${ }^{22}$ - $\mathrm{cl}$ autor más influyente en las ideas agraristas de la revolución, mismas que se plasmarían en la redacción del artículo 27 de la Constitución- de una reforma agraria sobre una base colectiva, y pidió también que se promoviera su industria artesanal. ${ }^{23}$

${ }^{21}$ Gamio, Forjando, 1992, pp. 93-101.

22 Basave, México, 2002.

23 Para entender la grandeza de Gamio, Brading, "Manuel", 1989, ha observado que mientras la generación independentista rescataba la cultura prehispánica para justificar la liberación de España, los liberales del siglo XIX interpretaban al indígena como una de las principales rémoras para el progreso y la construcción de una nación moderna, vieron en su cultura - siguiendo las ideas de Alexandro von Humboldt sobre el arte griego, para quien libertad política y belleza estética iban juntas- manifestaciones de la barbarie y la fealdad. Gamio, apoyándose en el antropólogo Franz Boas - con quien trabajó estrechamente-, refuta al darwinismo social de la época que postulaba que había razas que eran superiores a otras y colocaba a la blanca en el primer nivel. A esta visión Gamio opone el argumento de que todas tienen similares capacidades y
Por otra parte, el repudio a la violencia y la apuesta por los hombres forjadores de instituciones encontró a su mejor exponente en Manuel Gómez Morín. Con un lenguaje muy inspirado en José Ortega y Gasset, Gómez Morín opinaba que para refundar a la nación su generación debía encontrar la salvación en la "técnica"; la cual consiste en el uso de la crítica y el método para construir instituciones acordes a nuestro medio, adaptar lo universal a lo particular, abandonar la improvisación y el diletantismo. En pocas palabras, aplicar -dicho hoy en un lenguaje más popperiano- la "ingeniería social" para sacar al país de las ruinas en que lo dejó la revolución.

En un ensayo titulado significativamente "1915", ${ }^{24}$ escrito en 1926 y publicado en 1927, expresaba que la turbulencia política de la década que siguió a la revolución había impedido ver el sino de la época: la técnica constructivista. ${ }^{25}$ Sólo en 1920, con el "apostolado educativo"

cualidades. Asimismo, exigió una revalorización de las formas del arte indígena y que se rechazaran los cánones neoclásicos de la estética para juzgarlas, pues, argumentaba, apoyándose en el romanticismo europeo, que cada cultura debe juzgarse por sus cánones propios. Véanse también Potash, "Historiografía", 1961, p. 376; Florescano, "Memoria", 1995, p. 103; Villoro, "Cultura", 1960, p. 204. Sobre los argumentos del romanticismo véase Berlin, Corriente, 1992.

${ }^{24}$ Gómez, 1915, 1927.

${ }^{25}$ Gómez Morín no sólo argumentó en favor de la prudencia creadora del entramado institucional, él mismo trabajó activamente en esa tarea, por ejemplo, en la elaboración de la legislación hacendaria y bancaria de los años veinte. Para acelerar la reconstrucción del país invitaba a sus contemporáneos a que se proclamaran "generación de 1915", porque en este año nació el México nuevo y su destino es hacer de la técnica el método para resolver los grandes problemas nacionales. Para mayores datos véase Krauze, Candillos, 1985 , pp. 219-239. 


\section{SECUENCIA}

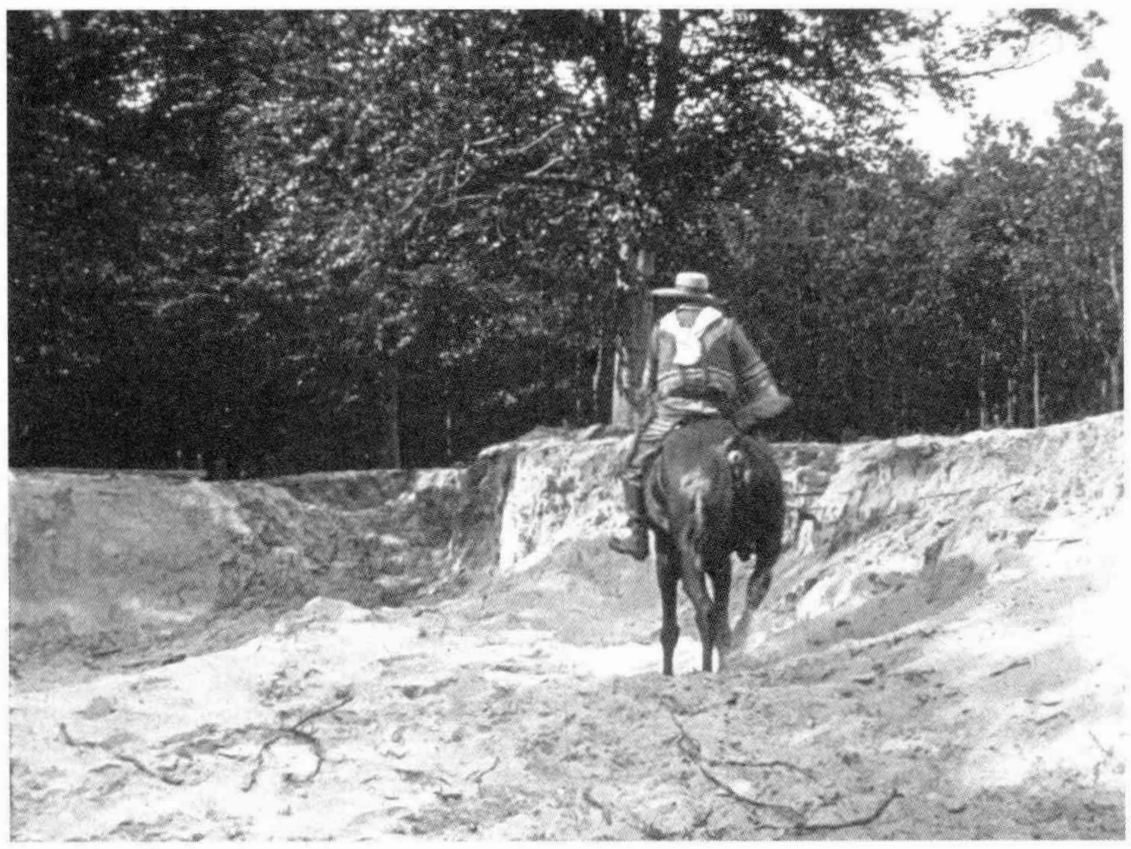


de José Vasconcelos, se mostró un primer atisbo. Era el momento, pues, de superar el romanticismo y el misticismo ${ }^{26}$ vagos de los días de la lucha revolucionaria.

Gómez Morín también introduce una de las primeras lecturas del significado de la revolución. Advierte que esta última dispersó a los intelectuales y provocó que su generación se quedara sin maestros (pues, salvo Antonio Caso, la mayoría huyó del país o siguió a los ejércitos revolucionarios), lo que, aunado al aislamiento en que se hallaba el país del exterior a raíz de la primera guerra mundial, obligó a su generación a "buscar en nosotros mismos un medio de satisfacer nuestras necesidades de cuerpo y alma". ${ }^{27} \mathrm{De}$ pronto, agrega, descubrimos algo: "Existía México. México como país con capacidades [...] con problemas propios [...] y los indios y los mestizos y los criollos, realidades vivas". El año de 1915 fue la noche más oscura de la revolución: "cuando la lucha parecía estar inspirada nomás por bajos instintos personales, empezó a señalarse una nueva orientación". El problema agrario empezó a surgir desde lo más hondo, con un "programa mínimo definido y para ser el tema central de la revolución", también aparece el problema obrero y la reivindicación nacionalista sobre "todo lo que pudiera pertenecernos: el petróleo y la canción, la nacionalidad y las ruinas".

${ }^{26}$ De hecho, la generación de intelectuales articulados en el Ateneo de la Juventud, cuyos miembros fueron los maestros de Gómez Morín, abrazaron el misticismo bergsoniano para atacar al positivismo que imperó durante el porfiriato. Ibid. Sobre el Ateneo de la Juventud véase Legrás, "Ateneo", 2003.

${ }_{27}$ Idea que retoma Paz, Laberinto, 2000, p. 164, en su evaluación de la revolución. Por ejemplo, aduce: "la revolución fue una brusca y mortal inmersión en nosotros mismos, en nuestra raíz y origen".
En el ensayo de Gómez Morín hay el reconocimiento de la prioridad de la política en la década posrevolucionaria y el ascenso desde el subsuelo hasta la palestra pública de las masas (el nuevo sistema de acción histórica) en búsqueda de resolver sus agravios y fundar un nuevo pacto histórico sobre el cual edificar el nuevo país. La generación de 1915, expresaba Gómez Morín, eran todos aquellos que vivieron esos acontecimientos trágicos y sentían que tanto dolor no sería inútil, por ello, su arquetipo debería ser la "reconstrucción" con método, crítica y técnica. Sólo así se podrían cumplir las banderas de la lucha armada (reforma agraria y laboral, nacionalismo) y heredar un mejor país a las siguientes generaciones. La suya, debía ser, entonces, un instrumento de la revolución.

En la década de 1930 aparecieron dos importantes obras de los economistas estadunidenses Frank Tannenbaum, ${ }^{28}$ Peace by Revolution de $1933^{29}$ y Eyler N. Simpson, The Ejido. Mexico's Way out de 1937, ${ }^{30}$ respectivamente, mismas que serán muy influyentes tanto en la historiografía sobre la revolución mexicana como en las propias elites políticas de los años treinta. ${ }^{31}$

Tannenbaum sostenía cuatro tesis centrales. Primero, afirmaba que la revolu-

${ }^{28}$ Para la biografía y fuentes intelectuales de este autor es de mucha utilidad el ensayo de Hale, "Frank", 1997.

${ }^{29}$ Aquí se hará referencia a la edición española de 1938.

${ }^{30}$ Esta obra será citada aquí en su edición española de 1953.

${ }^{31}$ Tannenbaum y Simpson aparecían así como los continuadores de una respetable historiografía estadunidense que incluía a talentosos estudiosos como Ernest Gruening y Carleton Beals, entre otros. Una buena reseña de esta tradición aparece en Meyer, Conciencia, 1970. 
ción de 1910 fue un movimiento espontáneo, "arraigado en la multitud de comunidades del campo", dirigido contra las haciendas -tesis sobre la que gira, como se verá, gran parte del debate con el revisionismo. Segundo, el movimiento obrero, en cambio, fue creado principalmente desde el Estado para equilibrar, mas no destruir, el poder con el gran capital, pero Tannenbaum se lamentaba de la corrupción que pronto imperó en el liderazgo sindical, así como de su conservadurismo -tesis que la historiografía estatalista sobre el movimiento obrero, especialmente la marxista, desarrollará a partir de los años setenta. Tercero, por ello creía que la salvación para lograr la democracia y estabilizar la revolución estaba en las comunidades agrarias, no en los sindicatos. Finalmente, opinaba que la escuela rural, junto con la reforma agraria, eran los medios para integrar más a la nación. ${ }^{32}$ Estas tesis de Tannenbaum, sin duda, son las que más influyeron en la elaboración de la imagen y el gran relato que esta generación heredaría a la siguiente. ${ }^{33}$

La historiografía de la década de 1910 había distinguido ya entre una revolución social y una revolución política, ${ }^{34}$ pero a partir de los años veinte muchos estudiosos

${ }^{32}$ Tannenbaum, $P a z, 1938$; véase también Hale, "Frank", 1997. Según Meyer, Conciencia, 1970, p. 147, Tannenbaum llega a México atraído sobre todo por la cuestión agraria y en todas sus obras insistirá en el papel fundamental que el problema de la tierra ha desempeñado en la historia del país. Sus libros están escritos no con el afán de condenar o salvar a México, sino de "comprender al país" desde el punto de vista científico.

${ }^{33}$ Otras obras de Tannenbaum en las que continúo desarrollando estas tesis fueron Mexican, 1929 y Mexico, 1950.

${ }^{34}$ Al respecto, véase Nava, "Apuntes", 1986. no dudaron en señalar la mayor importancia de la primera sobre la segunda. Gracias al ascenso de las movilizaciones campesinas en la década de 1920, que aprovecharon varios gobernadores de los estados, y las tendencias radicales dentro y fuera del país que se suscitaron después de la crisis mundial de 1929, el temperamento político se iba desplazando hacia la izquierda. Emiliano Zapata y no Francisco Villa ${ }^{35}$ aparecía como el principal héroe de la lucha armada, pues se trató, afirma Tannenbaum, "de un movimiento esencialmente agrario. Los otros aspectos de la revolución han sido incidentales y accesorios." 36

Acerca del maximato (1928-1934), Tannenbaum argumenta en $1933^{37}$ que las elites políticas se hallan divididas y titubeantes: oscilan entre apoyar a la hacienda y apoyar a los pueblos, pero aún no terminan por decidirse en una u orra dirección. Eyler Simpson, ${ }^{38}$ a diferencia de Tannenbaum que escribe en un tono ensayístico, desarrolla una sólida investigación empírica para dilucidar en dónde estaban los puntos finos que separaban a ambas facciones. Encuentra que de las muchas cuestiones involucradas la esencial era cómo resolver la reforma agraria: ¿se debería ver a los ejidos como un medio transitorio para educar al campesinado como un futuro pequeño propietario? $\mathrm{O}$, por el contrario ¿el ejido debería ser la

${ }^{35}$ Brading, Octavio, 2002, p. 18, afirma que "si durante la revolución la popularidad de Pancho Villa opacó a la figura de Emiliano Zapata, en la década de los treinta se dio un esfuerzo sostenido por instalar al dirigente de los campesinos de Morelos como el héroe verdadero de la revolución, la manifestación de su verdadera esencia".

36 Tannenbaum, Paz, 1938, p. 148.

${ }^{37}$ Ibid., pp. 200-208 y 245-251.

${ }^{38}$ Simpson, "Ejido", 1952, pp. 221-231. 
base sobre la cual impulsar el desarrollo agrícola del país y estabilizar al régimen posrevolucionario? El ala veterana apoyaba la primera opción y la agrarista la segunda. Entre 1933 y 1934 se desarrolló en el Partido Nacional Revolucionario (PNR) un enconado debate sobre estas dos cuestiones con miras a la elaboración del Plan Sexenal, con el que debería gobernar el presidente que resultara electo para el periodo 1934-1940.

Simpson, además de precisar las ideas de cada uno de los bandos contendientes, observa con agudeza que el Plan Sexenal se inspiraba en gran medida en los planes quinquenales desarrollados por Stalin en la URSS, pero considera que el de México, si bien le ganaba en años al soviético, era muy improvisado y no se apoyaba en una base estadística firme sobre la cual ejercer la planeación. Su función fue la de reunir en un documento las ideas contradictorias de los bandos beligerantes. Observa que si bien el ala agrarista consiguió mucho (por ejemplo agilizar los trámites para la dotación ejidal), imperaba el criterio del ala veterana: la propiedad privada, en especial la pequeña, debía ser el ideal de la reforma agraria. Al final de su obra, Simpson concluye con un argumento similar al de Tannenbaum: México debería apostar a la vía de los agraristas, el ejido es no sólo la salvación del campo mexicano sino también el camino para avanzar hacia una industrialización equilibrada. Lázaro Cárdenas fue el presidente que llegaría al poder con el mandato de su partido de poner en práctica el Plan Sexenal de 1934, pero inclinándose hacia las ideas agraristas. ${ }^{39}$

${ }^{39}$ Meyer, "Etapa", 1977, pp. 472-473; Tobler, Revolución, 1994, p. 640, y Hamilton, México, 1983. pp. 188-193.
El licenciado Ramón Beteta, ${ }^{40}$ en su carácter de director general de Estadística de México, escribió en julio de 1935, en pleno conflicto entre Lázaro Cárdenas y Plutarco Elías Calles, una conferencia que dictó en la Sección Latinoamericana del Instituto de Negocios Públicos de la Universidad de Virginia en Estados Unidos. El tema eran los aspectos económicos del Plan Sexenal. Beteta explica aquí el carácter peculiar de este último: no se trata de implantar el comunismo bolchevique, tampoco el liberalismo capitalista que se halla en crisis desde 1929 en los países industrializadọs. Se trata de hallar una vía mexicana ${ }^{41}$ que combine reforma agraria con industrialización, pero sin los males de los países desarrollados: "la aglomeración urbana, la explotación del hombre por el hombre, la producción para la venta en vez de para el consumo [...] la mecanización de los trabajadores". El Plan Sexenal, parte de la convicción de que el ejicło, como también lo expresara Simpson, es la salvación para los problemas de México. El sueño del gobierno cardenista, concluye Beteta, es el de

un México con ejidos y de pequeñas comunidades industriales dotadas por los adelantos de la electricidad y de buenos sistemas sanitarios; comunidades en donde la proclucción tenga como fin la satisfacción de las necesidades humanas. ${ }^{42}$

${ }^{40}$ Beteta, "Aspectos", 1950, pp. 205-214.

${ }^{41}$ Para las influencias externas e internas en los ideales del cardenismo véase Semo, "Cardenismo", 1993, y Hamilton, México, 1983.

${ }^{42}$ Esta exitosa defensa del Plan Sexenal le mereció a Beteta no sólo la felicitación de Lázaro Cárdenas, sino también una rápida promoción a la subsecretaría de Relaciones Exteriores, en la que tendría un desta- 
Pero si bien la reforma agraria era la bandera más cara de la revolución a la que el gobierno de Lázaro Cárdenas va a llevar más lejos que cualquier régimen posrevolucionario que le haya antecedido o sucedido, tampoco abandonó las demandas de los obreros. El mejor exponente de éstos, Vicente Lombardo Toledano, expresó el modo en que aquéllos entendieron su alianza con Cárdenas.

Inspirado en el materialismo histórico que predicaba la III Internacional (comunista) en los años treinta, Lombardo Toledano se convirtió de hecho en uno de los principales ideólogos del cardenismo. ${ }^{43}$ Así, en un discurso de marzo de 1939 , Lombardo entendía la transformación del PNR en el Partido de la Revolución Mexicana (PRM) ${ }^{44}$ como la encarnación de los ideales más caros de la revolución, donde confluían las masas y el ejército en un frente común. La revolución era interpretada como un proceso que en el ámbito interno se proponía barrer con los resabios del feudalismo que aún quedaban, en el externo, se trataba de una lucha antiimperialista. El PRM, agregaba, era la conse-

cado papel en las gestiones para poner en práctica la expropiación petrolera en marzo de 1938.

${ }^{43}$ En los años veinte Lombardo había militado en la Confederación Regional Obrera Mexicana (CROM) para abandonarla una vez que ésta cayó en desgracia tras el asesinato de Álvaro Obregón -ya que su líder Luis N. Morones fue visto por los obregonistas como uno de los principales sospechosos de su muerte. Durante el maximato, además de abrazar el marxismo, empezó a destacar como uno de los dirigentes más importantes del torrente sindical que culminaría en la fundación de la Confederación de Trabajadores de México (CTM) en febrero de 1936. Cuando estalla el enfrentamiento de Cárdenas con Calles no duda en apoyar al primero.

${ }^{44}$ Lombardo, "Partido", 1988, pp. 119-127. cuencia lógica del proceso al que se había encaminado la revolución y la lucha de clases, nacía no para servir a la voluntad de un caudillo sino desde la tierra, "desde abajo para servirle al pueblo". Dos son las ideas que el movimiento obrero deseaba que orientaran la conducta del PRM: primero, que no fuera un partido sectorial de los obreros, "quiere el proletariado que el partido sea un partido para todo el pueblo"; segundo, que respete el voto "de los sectores organizados [...]. Queremos representantes que vivan realmente la vida de cada sector." Sólo así el partido puede mantener el anhelo común de "salvar a la revolución mexicana".

En otras palabras, Lombardo justificaba la idea del frente común, tanto en el interior (contra el "feudalismo" representado principalmente por la hacienda) como en el exterior (nacionalismo antiimperialista y antifascista), y apelaba a un funcionamiento corporativo del partido. Pero si Lombardo encontraba en el cardenismo la etapa más sobresaliente y gloriosa de la revolución, para Luis Cabrera era la desviación más peligrosa de los principios revolucionarios. Así, desde dos enfoques distintos, uno marxista y otro liberal, ambos autores sostuvieron en los años treinta lo que puede considerarse el primer gran debate sobre el significado de la revolución.

En abierta polémica con "los modernos socialistas" encabezados por Lombardo Toledano, a los que despectivamente se refiere como "niños de teta de la revolución de ahora”, Cabrera ${ }^{45}$ evalúa, en su ensayo

45 En la década de 1910 Cabrera, además de haber sido uno de los hombres de confianza tanto de Madero como de Carranza, se convirtió en el principal teórico de la revolución, a él se debe la famosa frase de la "revolución es la revolución", pretendien- 
"La revolución de entonces (y la de ahora)" de $1936,{ }^{46}$ a los que considera los tres grandes principios que alentaron el movimiento revolucionario de 1910 (democracia, nacionalismo y justicia social -reforma agraria y laboral), mismos que a su juicio pueden resumirse y subordinarse a una sola palabra: libertad. Afirma que los "revolucionarios de ahora" (desde 1920 a 1936) niegan la libertad, creen que el "individualismo está bien muerto" y que aquella palabra es menos importante cuando se persigue "el bien de la sociedad", pero para los "revolucionarios de entonces" (1910-1917) era un concepto fundamental. Y aunque jamás lograron conquistarla, siguen aspirando a ella. ${ }^{47}$ Los revolucionarios de entonces querían la democracia para evitar los males de la dictadura; si bien el maderismo no encontró los medios adecuados para hacerla realidad, ello no

do aludir con ello ha que ésta es el imperio de la fuerza y la violencia con la que se tenía que destruir el antiguo régimen hasta sus últimas consecuencias en vez de las tibias reformas que puso en marcha el gobierno de Madero. Cabrera era uno de los hombres que acompañaban la comitiva de Carranza en su camino a Veracruz, una vez que aquél se vio obligado a huir ante la rebelión de Agua Prieta. Al ser asesinado Carranza, Cabrera abandonó la política y se convirtió en uno de los más duros críticos de los gobiernos posrevolucionarios. Véase una reseña de sus obras y trayectoria biográfica en Meyer, Luis, 1982.

16 Reproducido en Cabrera, Otras, 1975, pp. 788815.

${ }^{47}$ Para Cabrera no hubo muchas revoluciones sino una sola: comenzó en 1910 y terminó en 1917 , se trata, pues, de la revolución madero-carrancista -tesis que a partir de fines de la década de $1960 \mathrm{em}-$ pezará a atacar el revisionismo. Lo que siguió después fue la reconstrucción de un nuevo régimen. Pero aunque la revolución era una sola sus motivaciones eran muy complejas. Sólo para ilustrar sus diferentes dimensiones es que Cabrera distingue entre una trinidad implica que se abandone ese ideal como pretenden los revolucionarios de ahora para instaurar un neoporfirismo: nos hallamos, afirma

en las mismas condiciones exactamente en que nos encontrábamos en la época del general Díaz, con la sola diferencia de que mientras el general Díaz asumía históricamente la responsabilidad de gran elector, en la actualidad el gran elector es el Partido Nacional Revolucionario que dizque ausculta previamente el sentir de las masas por medio del plebiscito.

Punto por punto, Cabrera encuentra en la obra del cardenismo la desviación más peligrosa de los ideales de la revolución de 1910: no hay democracia; la reforma agraria sólo cambió de amo a los campesinos, del hacendado al banco ejidal; los obreros son esclavizados por una burocracia sindical que se vale de la cláusula de exclusión, y los padres de familia no tienen libertad para educar a sus hijos, pues el Estado pretende moldear a su antojo a la niñez. No obstante, cree que "el sol de la libertad no se apaga; se pone", pero serán otras las generaciones que lucharán por ella, pues los "revolucionarios de entonces" ya están viejos. A éstos no les queda más que predicar con el ejemplo: la acción y la palabra. Manuel Gómez Morín, ahora alejado de los gobiernos posrevolucionarios y fundador del Partido Acción Nacional (PAN) en 1939, fue uno de los personajes que escucharon estas prédicas

de revoluciones: política (que gira en torno a la bandera de la democracia), económica (que implica el problema agrario y laboral) y social (educación, religión). Dimensiones que retoman los estudiosos de la segunda y tercera generación. 
de Cabrera (de hecho, llegó a proponerle a este último la candidatura del PAN para las elecciones presidenciales de 1946).

Como se observa, pues, para Cabrera enderezar el rumbo de la revolución era ante todo un problema moral: abogar por un retorno al principio central de 1910, la democracia. Con una apreciación del cardenismo distinta a la de Cabrera, en la década de 1940 Jesús Silva Herzog y Daniel Cosío Villegas también harán un juicio moral de los regímenes posrevolucionarios y arribarán a la conclusión de que la "revolución ha muerto".

LA SEGUNDA GENERACIÓN: A LA SOMBRA DEL DESARROLLISMO Y EL RÉGIMEN AUTORITARIO 1940-1968

Algunos autores consideran que 1938 fue el año en el que el cardenismo alcanzó su momento climático: concreción de la alianza del régimen con el movimiento obrero, incorporación del campesinado a un partido que ahora se reorganizaba sectorialmente bajo las siglas de Partido de la Revolución Mexicana (PRM) y la expropiación petrolera. Con estas reformas el cardenismo afianzaba gran parte de los principios de la revolución, pero también ésta llegaba a su fin. ${ }^{48}$ En adelante, bajo su nombre el país tomaría otra dirección. Los principales protagonistas ya no serían las masas, las organizaciones sindicales dejarían de priorizar la resolución de sus agravios y se transformarían en instrumentos de control y gestión de conflictos laborales. Ahora, los hijos predilectos del régimen serían los empresarios, mismos que no habían dejado de prosperar desde el es-

${ }^{48}$ Meyer, "Periodización”, 1979, p. 191. tallido mismo de la guerra civil de 1910 , pues esta última afectó sobre todo a los hacendados. ${ }^{49}$

Así, en la década de 1940 con Manuel Ávila Camacho (1940-1946) y Miguel Alemán (1946-1952) se le da más prioridad al crecimiento económico que a las reformas sociales. Para ambos gobiernos la salvación de México no estaba en el ejido y una industria que complemente al campo, sino al revés, el objetivo central debía ser la industrialización.

Es en este escenario que algunos intelectuales, siguiendo la veta abierta por Luis Cabrera en los años treinta, postulan que la "revolución ha entrado en crisis" o bien que "ha muerto". El primero en inaugurar el balance de la revolución y anunciar, desde un enfoque marxista, que aquélla está en peligro de muerte, es Jesús Silva Herzog. ${ }^{50}$ En un texto de $1943^{51}$ anuncia que se trata de una crisis moral: después del cardenismo -régimen con el que colaboró- se han abandonado los principios y el empuje de la revolución, cuyos ideales están recuperados en la Constitución del 17 (justicia, tierra, trabajo, educación, nacionalismo). El político -el hombre público, el líder sindical y el líder campesino- se ha transformado en un "logrero". Se enriquece, se corrompe y se le aplaude. Es una gangrena que no se sabe si empezó arriba o abajo, pero que amenaza nuestra soberanía y la salud del cuerpo colectivo.

${ }^{49}$ Womack y Meyer, "Diálogos", 1980, p. 5, han observado que los negocios y la revolución corrieron juntos.

${ }^{50}$ Silva Herzog redactó en 1937 el informe con base en el cual se llevó a cabo la sentencia de expropiación de la industria petrolera (marzo de 1938). Entre 1940 y 1942 se había desempeñado como director de la Escuela Nacional de Economía.

st Silva, "Revolución", 1943, pp. 32-55. 
Dado que es casi seguro que Estados Unidos saldrá fortalecido de la guerra, se hace más urgente que superemos esa crisis; pues si bien no podemos enfrentarnos a ese país ni económica ni militarmente, sí podemos cuidar nuestra soberanía siguiendo el camino de la honestidad, la probidad y la austeridad espiritual. Sólo así nos hallaran débiles pero unidos. El autor examina cada esfera de la vida pública y observa el extravío de los principios revolucionarios. Por ejemplo, en lo que concierne a la educación, "el cuidado de la conciencia de la niñez se ha dejado en manos de la reacción católica".

De manera similar a Silva Herzog, pero desde un enfoque liberal, cuando ya se sabía que Miguel Alemán sería el sucesor de Ávila Camacho, escribirá Cosío Villegas, en noviembre de $1946,{ }^{52}$ que México padece desde hace algunos años una crisis que se agrava día con día, pero como en los casos de enfermedad mortal en una familia, nadie habla del asunto: "La crisis proviene de que las metas de la revolución se han agotado." Su ensayo se propone entender cuáles eran esas metas y cómo se agotaron. La primera fue el derrocamiento del porfirismo y la instauración de la democracia; en la segunda caen là reforma agraria y el movimiento obrero; en la tercera, "el tono nacionalista que tuvo la revolución al exaltar lo mexicano y recelar lo extranjero". Aunque hoy esas metas parecen lugares comunes y suenan huecas, en su momento no "sólo fueron novedades", sino que toda una generación se sacrificó por ellas y desviaron la ruta del país durante un cuarto de siglo, "y pueden cambiarla todavía hasta completar. la media centuria".

${ }^{52}$ Cosío, "Crisis", 1984, pp. 401-419.
Cosío se pregunta: si la revolución mexicana no era sino un movimiento "democrático, nacionalista y popular" llevado a cabo por hombres del pueblo -la tesis de Tannenbaum- ¿cómo es que fracasaron en cumplir sus metas? La razón fundamental radica en que todos sus líderes "fueron inferiores a la obra que la revolución necesitaba hacer: Madero destruyó el porfirismo, pero no creo democracia; Calles y Cárdenas acabaron con el latifundio, pero no crearon la nueva agricultura mexicana". No es que la revolución no haya creado nada, sino que todo lo ha hecho a medias y queda expuesta ante sus enemigos sin ganar los suficientes partidarios. Con todo, los logros de la revolución en sus tres metas mayores, opina Cosío, no han sido tan magros, y habrían bastado para mantener la autoridad moral de los gobiernos emanados de ella si a los ojos de la nación sus esfuerzos para conseguirlos aparecieran con probidad inmaculada. Empero, es humanamente imposible

conservar la fe en un gobernante mediocre y deshonesto. Así, una general corrupción administrativa, ostentosa y agraviante, cobijada siempre bajo un manto de impunidad |...] ha dado al traste con todo el programa de la revolución.

La única salida, es la erradicación tajante de esta gangrena que corroe el cuerpo social.

Cosío Villegas coincide con Silva Herzog en que el principal desprestigio para la revolución es la corrupción de su clase política, por tanto que la crisis de la revolución es moral, pero se aparta en sus propuestas para encontrar la solución. Cosío cree que el único rayo de esperanza, distante y lejano, es "que de la propia revolu- 
ción salga una reafirmación de principios y una depuración de hombres". Si no se logra esto, el país estará en peligro y "la regeneración vendrá de fuera, y el país perderá mucho de su existencia nacional".

Pero ¿cuál era la nueva forma en que los operadores de la industrialización y las políticas públicas entendían el nuevo rumbo que debía tomar la revolución? Los autores que siguen ofrecen algunas respuestas.

Así como Simpson brindó la mejor obra sobre la reforma agraria en los años treinta, apoyada en una amplia investigación documental y estadística, el economista estadunidense Sanford Mosk lo hizo sobre la industrialización en 1950 con su libro Industrial Revolution in Mexico. ${ }^{53}$ Mosk registra, entre otras cosas, la aparición de un grupo de empresarios con nueva mentalidad empresarial, mismo que emerge al calor de la industrialización durante los años de guerra y posguerra, el autor lo llama el "Nuevo Grupo" -cuyos ideólogos son empresarios como José Domingo Lavín en los años cuarenta y Juan Sánchez Navarro a partir de los cincuenta-, se agrupan sobre todo en la Cámara Nacional de la Industria de la Transformación (CNIT), fundada en 1942. Este Nuevo Grupo rivaliza por igual con los viejos empresarios decimonónicos, partidatios del no intervencionismo estatal (articulados en las ramas tradicionales de la economía: textiles, comercio, banca, entre otras), el capital extranjero y los empresarios que se asocian con éste. En especial, el Nuevo Grupo se compone de propietarios de pequeñas unidades industriales, cuya principal función era abastecer el mercado interno de productos que no se

53 Misma que al año siguiente fue traducida al español, véase Mosk, Revolución, 1951. podían importar durante la segunda guerra mundial. Su segunda característica es que usan capital mexicano y que no guardan buenas relaciones con la banca, asociada con los empresarios tradicionales. Temen la competencia de Estados Unidos y quieren para sí el mercado interno. El programa del Nuevo Grupo, afirma Mosk, propugna el nacionalismo económico, proteccionismo, subsidios, alianza con centrales campesinas y obreras para promover la industrialización. Consideran que esta última es el mejor medio para elevar el nivel de vida de la población. Son jóvenes y emprendedores, están acumulando mucho poder y coinciden con la política económica del Estado avilacamachista y alemanista. $^{54}$

En la filosofía que alentaba al gobierno cardenista, agrega, había poco espacio para la construcción de grandes plantas fabriles o para el desarrollo de centros industriales urbanos; la política agraria era la preocupación fundamental. No obstante, Mosk considera que Cárdenas, al tratar de apoyar al campo, emprendió un amplio programa de obras públicas (presas, carreteras, drenaje, escuelas, sistemas de irrigación) que ejercieron un efecto benéfico sobre todas las ramas de la industria, lo cual permitió contar con una base para la expansión de este sector durante los años de guerra. Sin embargo, su política expropiatoria generó fuga de capitales y obligó a los inversionistas potenciales a ser más cautelosos. En cambio, Ávila Camacho y Alemán invierten el orden de prioridades: la industrialización debía ser la meta central del país. Creían que era la nueva forma en que la revolución podía elevar el nivel de vida de las masas. Ambos llevan a cabo una

${ }^{54}$ lbid., pp. 30-57. 
política de subsidios, proteccionismo, financiamiento, exención de impuestos a industrias nuevas y estratégicas y ven en el Estado al promotor del desarrollo industrial. La diferencia entre uno y otro, concluye Mosk, radica en que el primero era cordial con el capital extranjero, mientras el segundo es abiertamente entusiasta y lo invita a invertir en el país. ${ }^{55}$

Muchos de los investigadores estadunidenses que escribieron sobre México en la posguerra se unieron a las voces que celebraban el desarrollismo mexicano y se oponían a las interpretaciones pesimistas de la revolución. La enfocaron desde el paradigma pluralista, entonces en boga en Estados Unidos, ${ }^{56}$ que postulaba la existencia de una correlación entre modernización y democracia. Cautivados por la rápida industrialización de México y reaccionando ante el triunfo de la tevolución cubana en 1959, empezaron a encontrar a la mexicana como "la revolución más madura de América Latina", hecha sin la ayuda del exterior y que orientó al país por un rumbo democrático, lejos del totalitarismo. Así, desde perspectivas más optimistas, las obras de Howard F. Cline, Mexico. Revolution to Evolution 1940-60 de $1963^{57}$ y James W. Wilkie, The Mexican Revolution. Federal Expenditures and Social Changes Since 1910 de 1967, ${ }^{58}$ argumen-

"ss El libro de Mosk desató una fuerre polémica con la elite intelectual, empresarial y política, por su crítica al gobierno en la falta de planeación para conducir la industrialización, misma que aparece reunida en el apéndice de la edición en español en 1951.

${ }^{56}$ Molinar, "Escuelas", 1993, pp. 3-56.

s' Una versión resumida de la misma fue traducida al español en 1981, véase Cline, "México", 1981, pp. 85-91.

${ }^{58}$ Traducida al español por el Fondo de Cultura Económica, véase Wilkie, Revolución, 1987, pp. 309 - taron, contra las apreciaciones pesimistas de Silva Herzog y Cosío Villegas, que la revolución mexicana no había muerto, sino que había evolucionado: de radical se transformó en armoniosa y abrazó a todos sus hijos en aras de un nacionalismo económico que pretendía una mayor integración de los mexicanos.

Empero, en 1963 apareció The Dilemma of Mexico's Development de Raymond Vernon -traducida al español en 1966-, que escandalizó a la elite política mexicana. Vernon introduce la primera nota discordante en plena euforia desarrollista. Observa $^{59}$ que a principios de los años sesenta el modelo económico adoptado por México desde la década de 1940, la economía mixta basada en un Estado intervencionista y en la sustitución de importaciones, muestra signos de cansancio; además, aparecen rivalidades entre "técnicos y políticos" en la elite gobernante, se reavivan los conflictos de intereses entre empresarios nacionalistas agrupados en la CNIT -el Nuevo Grupo-y los partidarios de la entrada del capital extranjero (CONCANACO y CONCAMIN); el mercado interno ha llegado a un techo y la posibilidad de competir en el exterior es escasa. Vernon considera que salvo el caso improbable de que aparezcan nuevas exportaciones importantes o nuevas oportunidades de sustitución de importaciones, "el estímulo tendrá que venir de adentro", lo que obliga a reformar el sistema político en dos posibles direcciones. La primera consiste en impulsar una presidencia fuerte similar a la que tuvieron Calles, Cárdenas o Ale-

\footnotetext{
317. Para un tratamiento crítico tanto de este autor como de Cline, véase Womack, "Mexican", 1971, y Molinar, "Escuelas", 1993.

${ }^{59}$ Vernon, Dilema, 1966, pp. 193-210.
} 
mán, pues desde la década de 1950 el presidencialismo, en su afán por controlarlo todo, tanto hacia la derecha como hacia la izquierda, se ha puesto una camisa de fuerza que le deja poco margen de maniobra; aunque de elegir esta alternativa, si el crecimiento económico no se reanuda, "es seguro que el gobierno mexicano incurrirá en la ira de muchos grupos influyentes y estimulará la discusión sobre la necesidad de ciertos cambios que se ven como posibles en el sistema político actual". La segunda opción, la más sensata, es impulsar un sistema de partidos políticos que permita generar cambios profundos en el sector privado de la economía, dándole más confianza para invertir. Así, se tendría que avanzar hacia el adelgazamiento del Estado, reduciendo su control sobre la economía con la esperanza de que las fuerzas dinámicas, liberadas por esa relajación, generen el crecimiento deseado. Un sistema de partidos permitiría también canalizar con mayor eficacia el procesamiento de las demandas de una sociedad más compleja y urbana, diferente a sobre la que se montó el sistema político presidencialista en sus inicios. Por desgracia, como sabemos hoy, los consejos de Vernon no fueron escuchados por la elite política.

En 1965 Pablo González Casanova terminó La democracia en México, libro que de inmediato se convirtió en un clásico. ${ }^{60}$ Desde los escritos de Silva Herzog y Cosío Villegas no aparecía una obra de ningún mexicano que hiciera un análisis tan profundo del sistema político posrevolucionario. Se trata de una investigación rigurosamente bien conducida, hecha con un enfoque multidisciplinario que reúne

\footnotetext{
${ }^{60}$ González, Democracia, 1965.
}

aportes de la antropología, el marxismo y la teoría de la modernización. ${ }^{61}$ Su argumento central es que el marginalismo y el colonialismo interno, ambos emanados del desarrollismo autoritario iniciado en la década de 1940, han introducido tensiones muy fuertes sobre el sistema político, por lo que si éste no se democratiza pronto, no podrá durar mucho tiempo. ${ }^{62}$ Es decir, por vías distintas González Casanova coincide con la conclusión a la que llegó Vernon.

González Casanova es posiblemente el autor de la segunda generación de estudiosos que observa con mayor agudeza lo que será el tema central de los escritores de la tercera generación que escribieron sobre la transición mexicana a la democracia: el desbordamiento del sistema político posrevolucionario por una sociedad civil que se hizo más compleja a medida que el desarrollismo cobraba vuelo y para la cual no había estructuras políticas que canalizaran su participación, o bien que no aceptaba las existentes y exigía la democratización del régimen. Es en este contexto que aparecen las tesis de la generación revisionista.

\section{LA INTERPRETACIÓN REVISIONISTA}

Las obras de John Womack, Zapata and the Mexican Revolution, 1969, y de Luis González, Pueblo en Vilo, 1968, ${ }^{63}$ se convirtieron en las pioneras del revisionismo a fines de los años sesenta, tras ellos vendría

${ }^{61}$ Para una reseña muy sugerente véase Segovia, Lapidaria, 1996, pp. 19-27.

${ }^{62}$ González, Democracia, 1965, pp. 144-160.

63 Womack, Zapata, 1969, y González, Pueblo, 1968. 
una pléyade de historiadores y científicos sociales de las más diversas corrientes teóricas que se propusieron analizar la revolución y sus resultados en distintas escalas de análisis: sus expresiones nacionales, regionales y locales. ${ }^{64}$

Varios factores alimentaron las inquietudes del revisionismo. La represión al movimiento estudiantil de octubre de $1968^{65}$ hizo desconfiar a los analistas de la tercera generación sobre la vocación democrática y la legitimidad revolucionaria del régimen; el carácter más radical y socialista de la revolución cubana hacía aparecer a la mexicana como una revolución tímida y "burguesa". ${ }^{66}$ Por si fuera poco, empezaba a quedar claro que el régimen no había cumplido con las promesas de justicia social: muchos campesinos aún carecían de tierras y el desempleo y la miseria se incrementaban a medida que se iba agotando el "milagro mexicano". Se imponía por tanto responder también a la pregunta de si el Partido Revolucionario Institucional (PRI) gobernaba para las masas o si no era más que un aparato de control de las elites políticas y económicas

${ }^{64}$ Espinosa, "Historia", 1978, p. 21, ha explicado de manera muy sintética el modo en el que en los años sesenta nace y prolifera la historiografía regional no sólo en México sino en el mundo occidental.

${ }^{65} \mathrm{Al}$ respecto la bibliografía es extensa. Un buen tratamiento del modo en el que los estudiantes interpretaban al régimen tanto antes como después de la represión del 2 de octubre puede encontrarse en Wences, Movimiento, 1971; una gúa sobre las diversas interpretaciones del movimiento estudiantil aparece en García, "Interpretaciones", 1980.

${ }^{66}$ Véase Bailey, "Historiografía", 1979, p. VII; Ross, Muerto, 1981, pp. 48-63; Rico, Pasado, 2000, pp. 221-222; Matute, "Actores", 1989, pp. 10-11, y Salmerón y Serrano, "Auge”, 2003, p. 188. que se habían beneficiado durante el desarrollismo mexicano.

Como ha visto Gloria Villegas, todas las corrientes historiográficas que aparecieron a fines de los sesenta tenían un común denominador: devolver "al proceso revolucionario su original y múltiple dimensionalidad, sepultada en la simplificación del discurso político gubernamental". ${ }^{67}$ Por su parte, Arnaldo Córdova considera que las explicaciones de los propios protagonistas del ' 68 sobre el sistema político mexicano no los satisfacían ni a ellos mismos; al volver a las aulas pensaron "que la derrota que acaban de sufrir se había debido, en lo esencial, a su ignorancia de la historia y de la realidad política de México". Por si fuera poco, el candidato del partido oficial en las elecciones presidenciales de 1970, Luis Echeverría, hizo su campaña "retomando los valores ideológicos de la revolución", con lo cual mostraba que, aunque por motivos diferentes, los propios grupos gobernantes trataban de revalorar nuestro pasado histórico. Podría decirse, entonces, afirma Córdova, "que el interés que todos hemos adquirido en el estudio de la revolución mexicana tiene una doble causa: académica, una, que se cifra en el progreso de los estudios históricos, y política, otra, que parte del ' 68 y que se desarrolla en la medida en que el país se democratiza y se politiza". ${ }^{68}$ En mi opinión, aquí aparecen con claridad las razones del distanciamiento (su afán por la objetividad) de la generación revisionista con el discurso oficial, así como sus apuestas valorativas (el compromiso): denunciar el carácter autoritario del régimen y promover los valores democráticos

\footnotetext{
${ }^{67}$ En Córdova et al., "Vieja", 1989, p. 23.

Gs Ibid., p. 18.
} 
(o, para la mayoría de los marxistas, los de la verdadera "revolución social", que sería cosa del futuro, no del pasado).

Javier Rico Moreno expresa el desencuentro del revisionismo con el régimen posrevolucionario en términos similares: en sus obras se percibe una motivación vinculada, ante todo, a una actitud del historiador en relación con su propia "historicidad". El espacio de experiencia

acogió a la incerridumbre primero, y el desencuentro después, en torno de la retórica del nacionalismo triunfante [...]. El presente, lejos de constituir la realización de las aspiraciones del pasado, se perfiló como una especie de tiempo abierto, susceptible de diversas direcciones. ${ }^{69}$

Las nuevas lecturas del pasado, aduce, no excluyeron la influencia de corrientes historiográficas externas: la escuela de los Annales, la creciente importancia de los estudios regionales sobre América Latina y el enfoque antropológico impulsado por la academia estadunidense. ${ }^{70}$

Sin embargo, a diferencia de la segunda generación, el revisionismo historiográfico no nace como resultado de un modelo teórico o metodológico que unifique a todos sus seguidores. Los analistas, en su búsqueda de una nueva interpretación de la revolución y de la formación del Estado posrevolucionario (1916-1940), han abrazado dos grandes vertientes o perspectivas que los han llevado a mantener vivas polémicas sobre el carácter de los mismos: una que trabaja a escala nacional y otra que lo hace en el ámbito regional.

${ }^{69}$ Rico, "Pasado", 2000, p. 221.

${ }^{70} 1$ lbid., p. 222.
La primera privilegia la forma en que el Estado se fue centralizando, sometió a las regiones y empaquetó en un modelo corporativo a los diversos actores de la sociedad civil que la lucha armada lanzó a la palestra pública. En esta perspectiva hay, a su vez, diversas interpretaciones, entre las que cabe destacar a la corriente marxista y a la autoritarista. La historiografía marxista ha tratado de dilucidar el carácter clasista de la revolución y del Estado posrevolucionario, entre sus mejores representantes encontramos a Arnaldo Córdova y a Adolfo Gilly. ${ }^{71}$ Este último aplicó al caso mexicano la tesis de León Trotsky sobre las revoluciones: se trata ante todo de la "irrupción violenta de las masas en el gobierno de sus propios destinos". Así, Gilly da cuenta de la forma en que las masas campesinas se esforzaron por gobernar sus propios destinos, especialmente en el caso del zapatismo, pero que terminan siendo vencidas por los ejércitos constitucionalistas. Por su parte, Córdova muestra el modo en que los orígenes clasemedieros y la experiencia e ideas de los principales ideólogos y dirigentes del movimiento de 1910 fueron conformando la ideología de la revolución mexicana y la propia edificación del nuevo régimen. ${ }^{72}$

Los partidarios del enfoque autoritarista se apoyan sobre todo en la sociología política desarrollada por Juan Linz ${ }^{73}$ para estudiar a los regímenes autoritarios. Des-

71. Una muestra de sus respectivas interpretaciones, así como la de otros autores marxistas, aparece en Gilly et al., Interpretaciones, 1979.

72 Gilly, Revolución, 1971; Córdova, Ideologia, 1981. Para una comparación entre los puntos de vista de ambos autores véase Matute, "Actores", 1989, pp. 1. $1-12$

${ }^{73} \mathrm{Linz}$, "Teoría", 1978. 
tacan la continuidad y discontinuidad que la revolución significó para las formas de control y estabilidad del nuevo régimen, observan la reconstrucción del Estado y el sistema político como el resultado de una mezcla de fuerzas e intereses localizados en las diferentes regiones que de forma gradual fueron sometidas desde el centro. Los más destacados exponentes de la escuela autoritarista son Lorenzo Meyer y José Luis Reyna. ${ }^{74}$ Además de explicar desde una perspectiva nacional el proceso de centralización del Estado que devino en un modelo corporativo, ponen de manifiesto la complejidad regional del mismo. En este sentido, los hallazgos de la historiografía regional afectan más a la interpretación marxista que a la autoritarista. Por ejemplo, véase la fuerte crítica de Romana Falcón ${ }^{75}$ a Arnaldo Córdova, autor que más firmemente defiende el carácter populista del Estado posrevolucionario.

La vertiente regional, en cambio, subraya la debilidad del Estado posrevolucionario y la diversidad de prácticas políticas en las regiones, muchas de las cuales fueron retomadas a escala nacional. Esta perspectiva, más que partir de alguna corriente teórica específica, se desarrolla en oposición a varias de las tesis (sobre el carácter de la revolución y la forma en que se formó el nuevo Estado) de los que trabajan desde la dimensión nacional. La proliferación de investigaciones regionales ha evidenciado así la complejidad de la revolución, los actores que participaron en ella y las pautas de reconstrucción del sistema político en diferentes estados. Sus descu-

${ }^{74}$ De Meyer, "Etapa", 1977, Conflicto, 1978, "Introducción", 1987, "Presidencialismo", 1993; Reyna, "Control", 1976, y "México", 1989.

${ }^{75}$ Falcón, "Surgimiento", 1987. brimientos lograron minar viejas imágenes y conceptos pero no ofrecen una nueva interpretación que sustituya a las anteriores. ${ }^{76}$ Hasta ahora son pocos los intentos para unir en forma sistemática a las dos grandes vertientes del revisionismo. ${ }^{77}$

No obstante, recientemente algunos autores han señalado la necesidad de unir los avances que han logrado tanto los que han trabajado en el ámbito nacional -a los que también se los califica como estatalistas $-{ }^{78}$ como en el regional -a los que con más frecuencia se les ha aplicado el mote de revisionistas- ${ }^{79}$ pues, a decir de Iacobs, si bien la historiografía regional nos ha proporcionado una riqueza de detalles sobre la revolución, o, mejor dicho,

${ }^{76}$ Los distintos puntos de vista de los autores que han trabajado a nivel regional aparecen en Brading, Caudillos, 1985 y en Martínez, Estadistas, 1988.

${ }^{77}$ Para algunos balances sobre los avances y limitaciones de las diferentes perspectivas véase Cárdenas, Reconstrucción, 1992; Alvarado, Portesgilismo, 1988; Iacobs, Revolución, 1990; Knight, "Revolución”, 1986, y Falcón, "Revoluciones", 1985.

${ }^{78}$ Knight, "Revolución", 1986, originalmente acuñó este término para criticar ciertas interpretaciones que han enfatizando el papel del Estado como el de un actor central de un proceso que lo lleva a su autorreconstrucción: por encima de la sociedad se hace aparecer al Estado como una entidad que actúa sobre otros actores más de lo que actúan sobre él. Sin embargo, el término ha sido extendido para agrupar a la mayoría de los estudios que colocan su objeto de estudio (la revolución y/o el Estado) en una escala nacional. Véase, por ejemplo, Cárdenas, Reconstrucción, 1992, pp. 7-24, y Alvarado, Portesgilismo, 1988.

${ }^{79}$ Falcón, "Revoluciones", 1985. Auque Knight precisa que en estricto sentido el revisionismo se compone de la mayoría de los estudios regionales/locales y como mínimo tres de las seis grandes síntesis que se han hecho hasta ahora sobre la revolución y el nuevo régimen: las de Jean Meyer, François-Xavier Guerra y Ramón Eduardo Ruiz. 
sobre las diversas revoluciones locales así como sobre los diversos actores revolucionarios, está resultando algo indigesta, ya que a la "desintegración del antiguo consenso no la ha seguido la aceptación general de una nueva perspectiva". ${ }^{80}$ Por su parte, Joseph, si bien está de acuerdo en que la nueva historiografía ha captado la significación de la revolución en sus matices más oscuros y ha llamado poderosamente la atención sobre las importantes continuidades existentes entre el régimen porfirista y el Estado posrevolucionario, siguiendo a Knight afirma que los revisionistas exageran el anterior argumento. Enfatizando la continuidad antes que la ruptura, "postulan el surgimiento de un gobierno central maquiaveliano como el elemento decisivo de la revolución épica". Así, sustituyen la visión tradicional de la revolución, el avance "benigno" de ésta hacia la justicia social, por el "avance maligno -o neutral- del Estado hacia la integración nacional y la burocracia centralizada". Como ha demostrado Knight, tal estatolatría dota de un carácter homogéneo al complejo proceso que fue la revolución mexicana: complejidad que irónicamente los revisionistas han documentado en sus estudios regionales. Asimismo, tal revisionismo "se olvida de las presiones ejercidas sobre el Estado; erróneamente destaca la inercia de los campesinos y obreros, así

${ }^{80}$ Iacobs, Revolución, 1990, pp. 14 y ss.; véanse también Knight, Interpreting, 1988; Falcón, "Revoluciones", 1985, y "Revisionismo", 1987; Joseph y Wells, "Replanteamiento", 1994. Para superar el panorama tan abigarrado a que nos ha lievado la historiografía regional Knight, Interpreting, 1988, propone regresar a los teóricos de la primera generación; Falcón, "Revoluciones", 1985, p. 364, en cambio, sugiere que se deben revisar las tesis de los mismos revisionistas. como la hegemonía política continua de las elites y los estratos medios". ${ }^{\prime 1}$

De este modo, estatalistas y regionalistas -las dos grandes vertientes del revisionismo- se hallan inmersos en un clebate todavía irresoluble. Pero unos y otros, como ha observado Joseph en sus respectivas evaluaciones de la revolución y el Estado posrevolucionario, tienden a coincidir en un punto: subrayan más la continuidad que la discontinuidad entre el antiguo régimen porfirista y el que emerge de la revolución. Niegan el carácter social $^{82}$ de la revolución y subrayan que se trató más de un pleito político entre "elementos frustrados de las clases altas y elementos favorecidos de las mismas clases". En esa lucha, señala Womack, intervinieron las masas populares pero de modo "intermitente, con diferencias regionales, y las más de las veces dirigidas por la clase media, menos en causas económicas y sociales que en una guerra civil burguesa". Por ello, aduce, el tema de la historiografía de la revolución ya no es tanto "la revolución social como la gestión polícica", es más importante contar la historia de la derrota y subordinación de los movimientos populares que el significado de su participación en la revuelta. A pesar de la violencia de la década de 1910, Womack resume del siguiente modo el principal significado histórico de la revolución y el carácter del Estado que emerge de ella:

tenacidad capitalista en la economía y reforma burguesa del Estado, lo que contribuye a explicar la estabilidad del país durante las luchas de los decenios de 1920 y 1930 y su

81. Knight, "Revolución", 1986, p. 16.

${ }^{82}$ Para un tratamiento teórico de este término véase Skocpol, Estados, 1984. 
crecimiento extraordinario y discordante después de $1940 .{ }^{83}$

Es justamente este énfasis en la continuidad más que en la ruptura entre el antiguo régimen y la revolución lo que lleva a autores de las más diversas corrientes del revisionismo a mantener, a pesar de sus diferencias, una impronta común de la época en que escriben: el desencanto con la revolución social ${ }^{84} \mathrm{y}$ una subestimación de la irrupción de las masas en la palestra pública, que sí enfatizaban los autores de la primera generación y que no negaban los de la segunda. No es casual así que un marxista como Arnaldo Córdova ${ }^{85}$ y un escritor procatólico como Jean Meyer ${ }^{86}$ coincidan con lo que afirma un liberal como Womack.

${ }^{83}$ Womack, "Revolución", 1992, pp. 79-81.

${ }_{84}$ Mismo que de acuerdo con la corriente teórica a la que pertenezca el autor en cuestión tiene diferentes razones. Para el marxista la no llegada del socialismo, la revolución mexicana le parece desvirtuada (desviada, internumpida); el liberal observa una revolución en la que las elites triunfan sobre las masas para propiciar el capitalismo, pero sin democracia; para el católico, es la historia de unas elites revolucionarias que no respetan la religiosidad católica popular en aras de impulsar un proyecto estatal moderno secularizante.

${ }^{85}$ Para este autor la revolución fue un movimiento político que hizo reformas sólo de manera incidental para dominar a las masas, la meta esencial de sus líderes era promover el capitalismo. Córdova, Ideología, 1981.

${ }^{86}$ Meyer, Cristiada, 1993, ve la emergencia de un Estado autoritario que ya sea con reformas o por medio de la violencia somete a las masas. Está de acuerdo en que la revolución fue política y no social. Lo único que tiene de revolucionaria es su cruzada para someter al México antiguo, tradicional y católico, forma parte pues de un viejo proceso de una cruzada
Empero, más allá de las debilidades y fortalezas del revisionismo - tarea que aún está pendiente- ${ }^{87}$ lo cierto es que éste se ha construido - si se me permite la expresión- desde nuestro presente más inmediato, bajo la influencia de las corrientes teóricas e ideológicas (los "tiempos del mundo") que han soplado en el último tercio del siglo Xx. Empero, para una mejor comprensión de la revolución mexicana, es necesario no sólo escuchar la voz de nuestros estudiosos contemporáneos, la de los revisionistas, que con sus filias y sus fobias pueden borrar u oscurecer la de quienes los han precedido, sino también regresar a leer a cada una de las generaciones de nuestra centuria que se han esforzado por interpretarla. Tal vez ello pueda ayudar a "enfriar el objeto" y observar con mayor distanciamiento y neutralidad tanto a la revolución mexicana como a sus resultados (también objeto de encendidos debates).

liberal contra el catolicismo de los mexicanos y la Iglesia. Las coincidencias entre Córdova y Meyer han sido observadas por Bailey, "Historiografía", 1979, p. vil, pero en mi opinión ello es válido también para Womack.

${ }^{87}$ Florescano, Nuevo, 1999, p. 147, ha argumentado que el revisionismo en sus distintas verticntes (marxista, liberal, católica y autoritarista) si bicn ha permitido una mejor y más fina apreciación de diferentes dimensiones de la revolución, la sociedad y el Estado que emergen de ella ha tendido a elaborar nuevas teleologías privilegiando el análisis de los procesos de larga duración en los que el tema central son las causas y los resultados de la revolución, pero cue pierden de vista el fenómeno esencialmente político que es la revolución: el ascenso de una sociedad en armas que anda en busca de un nuevo pacto histórico, a través de sus representantes, sobre el cual edificar un nuevo poder. 


\section{CONCLUSIONES}

La mayoría de los autores que escribieron entre 1910 y 1940 son ensayistas o historiadores amateurs -aunque, como se ha visto, había notables excepciones- que escriben apoyándose en poca investigación empírica, o bien se refugian en la monografía con escasos comentarios críticos, pero no por ello menos partidaristas. Sus ideas aparecen cuando aún se podía oler la pólvora disparada en la guerra civil (Luis Cabrera, Manuel Gamio) o cuando en la memoria colectiva todavía estaba fresco el recuerdo de la misma (Manuel Gómez Morín, Ramón Beteta). En esta generación hay, pues, obras o memorias de los actores participantes (Obregón, Calles, Vasconcelos, posiblemente este último es el caso más paradigmático del gusto por las memorias en el público de la época, pues las suyas pronto se convirtieron en best sellers), observadores y testigos de los hechos. ${ }^{88}$ De esta suerte, la mayoría de ellos no podía eludir el compromiso político y les era muy difícil construir explicaciones distanciadas, más objetivas. Así, hay escritores tanto de derecha (católicos, hispanistas) como de izquierda (liberales, marxistas, anarcosindicalistas), locales y extranjeros (especialmente anglosajones). ${ }^{89}$

${ }^{88}$ En palabras de Potash, "Historiografía", 1961, pp. 371-72, "después de 1929 el gotear de memorias se convirtió en un torrente bramador, apareciendo año con año volúmenes que llenaban los anaqueles de las memorias revolucionarias". Para mayores referencias de las mismas, además de la bibliografía que este autor proporciona, véase González y Ross, Fuentes, 1961-1967, vol. 2, pp. 359-460.

${ }^{89}$ Benjamín, "Revolución", 1996, pp. 445-453; Florescano, Nuevo, 1999, p. 72, y Michaels, "Nacionalismo", 1966, pp. 213-238.
La mayor parte de los autores de la segunda generación empezó a publicar el resultado de sus investigaciones en los años cincuenta y sesenta. ${ }^{90} \mathrm{~A}$ diferencia de sus predecesores, esta nueva oleada de analistas apoya sus obras en una amplia investigación documental extraída tanto de archivos hasta entonces inexplorados como de fuentes secundarias. Sus interpretaciones optimistas de la lucha armada prácticamente coincidían con las que predicaba el régimen. ${ }^{91}$ Varios factores hicieron creer a la segunda generación que la revolución estaba triunfando: la estabilidad política alcanzada desde fines de los años treinta, basada en un partido que había empaquetado de manera corporativa a las masas y gobernaba a nombre de ellas enarbolando los ideales de 1910 registrados en la Constitución de 1917 y el gran dinamismo de una economía mexicana que había emprendido su marcha hacia la industrialización desde los años de la segunda posguerra. Todo ello llevó a una versión prácticamente unánime sobre la explicación del proceso revolucionario.

En contraste con la primera ronda de estudiosos, en la que imperan las interpretaciones liberales, marxistas o conservadoras, en los analistas de la segunda generación el paradigma de interpretación predominante es el pluralista, ${ }^{92}$ cuya tesis

${ }^{90}$ Mayores datos sobre los autores de esta segunda generación pueden encontrarse en Ross, "Aportación", 1960, pp. 285-295 e "Historia", 1965, pp. 426-429; Bailey, "Historiografia", 1979, p. III; Florescano, Nuevo, 1999, pp. 72-74; Womack, "Mexican", 1971, pp. 481-83, y Molinar, "Escuelas", 1993.

${ }^{91} \mathrm{Al}$ respecto puede consultarse lópez et al., México, 1960-1962, especialmente el vol. 4.

${ }^{92}$ Este paradigma a su vez se nutre por tres corrientes teóricas: el institucionalismo de la posguerra 
central es ésta: la modernización de una sociedad conduce a una mayor pluralización de su comunidad política, promoviendo así una creciente democratización. ${ }^{93}$ En otras palabras, observa una asociación unilineal entre cambio socioeconómico y cambio político. De ahí que sus temas predilectos sean la cultura política, las formas de representación, el apego a derecho, el proceso de toma de decisiones y la eficiencia administrativa, así como los soportes económicos de todo ello: distribución del ingreso, crecimiento, desarrollo, industrialización.

El optimismo general sobre la revolución y sus resultados que imperó hasta la década de 1960 es rechazado tajantemente por los analistas de la tercera generación. La historiografía revisionista retoma a los pocos autores que en medio de la euforia đè las épocas anteriores, que celebraban la fiesta de la "revolución institucionalizada", se habían mostrado escépticos, especialmente Jesús Silva Herzog y Daniel Cosío Villegas. Ambos desde la década de

que predicaba una relación entre desarrollo capitalista y democracia política -su mejor exponente es Seymour M. Lipset. El funcionalismo en sus tesis sobre el paso de una sociedad tradicional a una moderna -su mejor figura en la sociología es Talcott Parsons. Y la teoría de la modernización que centra sus baterías en la explicación del cambio social recuperando todo lo anterior -por ejemplo, Amitai Etzioni, Joseph La Palombara, Gino Germani.

93 Molinar, "Escuelas", 1993, revisa el modo en el que cada uno de los teóricos de la segunda generación utilizan el paradigma pluralista. No obstante, difiero de Molinar al calificar a todos los que escribieron antes de la segundâ gènèración como "ensayistas no científicos". Pues si bien ello es verdad para la mayoría de los autores había buenas excepciones: por ejemplo los casos de Manuel Gamio, Eyler Simpson, Frank Tannenbaum, Ernest Gruening y Carleton Beals.
1940 habían argumentado que la revolución había muerto cuando ésta abandonó los ideales de justicia social para emprender el camino de la industrialización clurante la posguerra. Cosío Villegas además se propuso cuestionar de manera indirecta a la revolución al emprender y coordinar una amplia investigación sobre el porfiriato. ${ }^{94}$ Para su equipo de investigadores el porfiriato y no la revolución -como postulaba la mayoría de los analistas de la segunda generación- había lanzado a México hacia la modernización. Pero si esto era así se abrían dos preguntas: qué era la revolución y qué había logrado. La historiografía revisionista articuló su programa de investigación en torno a estas dos cuestiones.

Las dos primeras generaciones observaron con cierta claridad la ruptura y las discontinuidades entre el antiguo y el nuevo régimen emanado de la revolución: se trató de un movimiento popular, nacionalista y antiimperialista que buscaba la justicia social y el desarrollo del país. En cambio, la tercera, empeñada en desenmascarar el discurso oficial, tiende a mostrarse más distanciada de su objeto de estudio. Con esta postura ganó en objetividad, pero perdió de vista el tema de la ruptura, el carácter popular de la lucha armada y la emergencia de lo que Furet denomina "un nuevo sistema de acción histórica”. Se concentró en las continuidades entre el Estado emergido de la guerra civil y el que lo precedió. Esto es juzgar al movimiento revolucionario por sus resultados más que por el proceso por el que atravesó. Considero que la posición metodológica más adecuada no es tomar partido por una u

${ }^{91}$ Hale, "Liberal", 1974. 
otra postura, ${ }^{95}$ sino tratar de utilizar lo mejor de ambas: rearticular la explicación de la ruptura, las discontinuidades y las continuidades en una nueva síntesis: Pues cuando se vuelve la mirada sobre amplios tramos de la corriente histórica se obtiene una imagen más equilibrada de la misma si se combinan dos perspectivas metodológicas: la del nadador que observa desde dentro de la corriente (esto es la postura del compromiso) y suele advertir con mayor prontitud cuán diversos son muchas veces los caminos y senderos que pueden seguir las estructuras, procesos y tensiones de un tipo determinado para convertirse en estructuras de otro tipo (esto es, la explicación de la ruptura del orden social), con la del sujeto que mira desde la atalaya del presente y pone de manifiesto el modo en que la historia tiende a precipitarse en una dirección determinada (la actitud del distanciamiento, desde la cual es posible mirar con mayor claridad las continuidades del orden social). Ambas miradas ponen el acento en aspectos parciales, sólo de su conjunción se pueden presentar imágenes más equilibradas de la realidad.

\section{BIBLIOGRAFÍA}

- Aguilar Camín, Héctor, La frontera nómada: Sonora y la revolución mexicana, Siglo XXI, México, 1984.

- México: la ceniza y la semilla, Cal y Arena, México, 2000.

95 De hecho, lo que parece perfilarse como una cuarta generación de estudiosos, la "nueva historia cultural", tiende a deslizarse hacia la actitud del compromiso: localización del discurso y las prácticas políticas de los actores de la revolución. Véanse Barrón, Historias, 2004, y Knight, "Subalterns", 2002.
-Alvarado, Arturo, "El portesgilismo en Tamaulipas. Estado y región en el México contemporáneo", tesis de doctorado, Crs-Colmex, México, 1988.

-Bailey, David, "El revisionismo y la historiografía reciente de la revolución mexicana", La Cultura en México, suplemento de Siempre!, 4 de mayo de 1979, pp. II-VIII.

, "Sobre la historiografía de la revolución mexicana”, Siempre!, 4 de mayo de 1979, pp. II-VIII.

-Barrón, Luis, Historias de la revolución mexicana, FCE, México, 2004.

-Basave Benítez, Agustín, México mestizo. Análisis del nacionalismo mexicano en torno a la mestizofilia de Andrés Molina Enríquez, FCE, México, 2002.

-Benjamín, Thomas, "La revolución es regionalizada. Los diversos Méxicos en la historiografía revolucionaria" en Thomas Benjamín y Mark Wasserman (coords.), Historia regional de la revolución mexicana. La provincia entre 1910-1929, Conaculta, México, 1996.

-Berlin, Isaiah, Contra la corriente. Ensayos sobre bistoria de las ideas, FCE, México, 1992.

-Beteta, Ramón, "Aspectos económicos del Plan Sexenal" en Pensamiento y dinámica de la revolución mexicana. Antología de documentos políticosociales, México Nuevo, México, 1950, pp. 205214.

-Blanco, José Joaquín, Se llamaba Vasconcelos. Una evocación crítica, FCE, México, 1996.

-Brading, David A. (comp.), Caudillos y campesinos en la revolución mexicana, $\mathrm{FCE}$, México, 1985.

- "Manuel Gamio y el indigenismo oficial en México", Revista Mexicana de Sociología, vol. LI, núm. 2, abril-junio de 1989, pp. 267-303.

- Octavio Paz y la poética de la bistoria mexicana, $\mathrm{rCE}$, México, 2002.

-Cabrera, Luis, "La revolución de entonces (y la de ahora)" en Obras completas, Oasis, México, 1975 , vol. 3, pp. 788-815. 
1975.

, Obras completas, Oasis, México,

-Cárdenas, Nicolás, La reconstrucción del Estado mexicano. Los años sonorenses (1920-1935), UAMXochimilco, México, 1992.

-Carr, Barry, "Recent Regional Studies of the Mexican Revolution", Latin American Research Review, núm. 15, invierno de 1980, pp. 3-14.

-Cline, Howard F., "México: versión madura de una revolución latinoamericana" en Stanley R. Ross (ed.), ¿Ha muerto la revolución mexicana?, Premia, México, 1981, pp. 89-91.

-Comas, Juan, Manuel Gamio. Antología, UNAM, México, 1975.

-Córdova, Arnaldo, La ideología de la revolución mexicana. La formación del nuevo régimen, México, Era, 1981.

- et al., "Vieja revolución ¿Nueva Historiografía?", Universidad de México, vol. xulv, núm. 466, noviembre de 1989, pp. 18-40.

-Cosio Villegas, Daniel, "La crisis de México" en Enrique Krauze (comp.), Daniel Cosío Villegas. El bistoriador liberal, FCE, México, 1984, pp. 401-419.

-Elias, Norbert, Compromiso y distanciamiento. Ensayos de sociologia del conocimiento, Barcelona, Península, 1990.

-Espinosa, Lidya, "Historia regional: el rincón de la fatalidad", Nexos, núm. 7, julio de 1978, p. 21.

-Falcón, Romana, "Las revoluciones mexicanas de 1910", Estudios Mexicanos/Mexican Studies, vol. I, núm. 2, 1985, pp. 362-368.

, "El revisionismo revisado", Estudios Sociológicos, vol. v, núm. 14, 1987, pp. 341-351. - "El surgimiento del agrarismo cardenista. Una revisión de las tesis populistas", Historia Mexicana, vol. xxviI, núm. 3, eneromarzo de 1987.

-Florescano, Enrique, "Minucias para una historia mayor", Nexos, núm. 23, junio de 1978. $\longrightarrow$ El poder y la lucha por el poder en la bistoriografia mexicana, 1NAH, México, 1980.
"De la memoria del poder a la historia como explicación" en Carlos Pereyra et al., Historia ¿Para qué?, Siglo XXI, México, 1995.

Arena, México, 1999.

-Furet, François, Pensar la revolución francesa, Petrel, Barcelona, 1980.

-García Salord, Susana, "Interpretaciones del movimiento estudiantil del 68", Cuadernos Politicos, núm. 25, julio-septiembre de $1980, \mathrm{pp}$. 71-84.

-Gamio, Manuel, Forjando patria, Porrúa, México, 1992.

-Gilly, Adolfo, La revolución interrumpida, El Caballito, México, 1971.

- et al., Interpretaciones de la revolución mexicana, Nueva Imagen, México, 1979.

-Gómez Morín, Manuel, 1915, Cultura, México, 1927.

-González Casanova, Pablo, La democracia en México, Era, México, 1965.

-González y González, Luis, Pueblo en vilo, Col_mex, México, 1968.

México, 1997.

—_- "El quehacer histórico en México", Nexos, núm. 241, enero de 1998, pp. 269-271.

- y Stanley R. Ross, Fuentes de la bistoria contemporánea de México, COLMEX, México, 1961-1967, vol. 1.

-Guerra, François-Xavier, "Teoría y método en el análisis de la revolución mexicana", Rerista Mexicana de Sociología, vol. LI, núm. 2, abril-junio de 1989 , pp. 25-65.

$\longrightarrow$, México: del antiguo régimen a la revolución, FCE, México, 1991, 2 vols.

-Hale, Charles, “The Liberal Impulse: Daniel Cosío Villegas and the Historia Moderna de México", Hispanic American Historical Review, vol. LIV, núm. 3, 1974, pp. 479-498.

___. "Frank Tannenbaum y la revolución mexicana", Seczencia, núm. 39, septiembrediciembre de 1997, pp. 127-166. 
-Hamilton, Nora, México: los límites de la autonomía del Estado, Era, México, 1983.

-Hansen, Roger D., La politica del desarrollo mexicano, Siglo XXI, México, 1971.

-Héau Lambert, Catherine y Enrique Rajchenberg, "La leyenda negra y la leyenda rosa en la nueva historiografía de la revolución mexicana", Revista Mexicana de Sociología, vol. LIV, núm. 3, julio-septiembre de 1992, pp. 175-188.

-Hodges, Donald y Ross Gandy, El destino de la revolución mexicana, El Caballito, México, 1977.

-Hoyo, Eugenio del, "Historiografía mexicana en el siglo XX", Humanitas, núm. 20, 1979, pp. 231-241.

-Iacobs, Ian, La revolución mexicana en Guerrero. Una revuelta de los rancheros, Era, México, 1990.

-Joseph, Gilbert, Revalución desde afuera, $\mathrm{FCE}$, México, 1990.

- y Allen Wells, "Un replanteamiento de la movilización revolucionaria mexicana: los tiempos de la sublevación en Yucatán, 19091915", Historia Mexicana, vol. XLIII, núm. 3 , 1994.

-Knight, Alan, "La revolución mexicana: ¿Burguesa, nacionalista o simplemente una gran rebelión?", Cuadernos Políticos, núm. 48, octubrediciembre de 1986.

- Interpreting the Mexican Revolution, ILAS, Univesity of 'Texas at Austin, 1988 (Texas Papers of Mexico, 88).

- "Interpretaciones recientes de la revolución mexicana", Secuencia, núm. 13, eneroabril de 1989, pp. 23-43.

México, 1996, 2 vols.

- _- "Subalterns, Signifiers, and Statistics: Perspectives on Mexican Historiography", Latin American Research Review, vol. xxxvI, núm. 2, 2002, pp. 136-158.

-Krauze, Enrique, Caudillos culturales en la revolución mexicana, SEP/Siglo XXI, México, 1985.
Biografia del poder: caudillos de la revolución mexicana (1910-1940), 'Tusquets, México, 1997.

-Kuhn, Thomas, La estructura de las revoluciones científicas, FCE, México, 1990.

-Legrás, Horacio, "El Ateneo y los orígenes del Estado ético en México", Latin American Research Review, vol. XXXVIII, núm. 2, 2()03, pp. 34-60.

-Linz, Juan, "Una teoría del régimen autoritario. El caso de España" en Stanley G. Payne, Política y sociedad en la España del siglo XX, Akal, Madrid, 1978.

-Loaeza, Soledad, "El cambio político en México en el siglo XX. Analogías y orígenes de la discontinuidad de 1988" en Memorias del simposio de bistoriografía mexicanista, Comité Mexicano de Ciencias Históricas/Gobierno del Estado de Morelos/ IIH-UnAm, México, 1990, pp. 529-539.

-Lombardo Toledano, Vicente, "El Partido de la Revolución Mexicana" en Vicente Lombardo Toledano. La revolución mexicana, 1921-1967, INEHRM, México, 1988, pp. 119-127.

-López Mateos, Adolfo et al., México, 50 años de revolución, FCE, México, 1960-1962, 4 vols.

-Matos Moctezuma, Eduardo, "Manuel Gamio" en Enrique Florescano y Ricardo Pérez, (comps.), Historiadores de México en el siglo XX, FCE, México, 1996.

-Martínez Assad, Carlos (coord.), Estadistas, caciques $y$ caudillos, UNAM, México, 1988.

, Balance y perspectivas de los estudios regionales en México, IIH-UNAM, México, 1990.

Matute, Álvaro, "Orígenes del revisionismo historiográfico de la revolución mexicana”, Signos Históricos, vol. $\mathrm{I}$, núm. 3, junio de 2000 , pp. $29-48$.

"Historia política" en Juan A. Ortega y Medina et al., El bistoriador frente a la bistoria. Corrientes bisotiográficas actualer, UNAM, México, 1999, pp. 75-85. 
- "Los actores sociales de la revolución mexicana en 20 años de historiografía (1969-1989)", Universidad de México, vol. XI.IV, núm. 466, noviembre de 1989, pp. 10-17.

-Medina, Luis, "Origen y circunstancia de la idea de unidad nacional" en Lecturas de política mexicana, Colmex, México, 1977, pp. 77-114.

, "Historia contemporánea de México. ¿Tema de Historiadores?" en Gisela von Wobeser (coord.), Cincuenta años de investigación histórica en México, IH-UNAM/Universidad Autónoma de Guanajuato, México, 1998, pp. 293-311.

-Meyer, Eugenia, Luis Cabrera: teórico y crítico de la revolución, FCE, México, 1982.

- Conciencia bistórica norteamericana sobre la revolución de 1910, INAH, México, 1970.

-Meyer, Jean, "México: revolución y reconstrucción en los años veinte" en Leslie Bethel (ed.), Historia de América Latina, Crítica, Barcelona, 1992, vol. 9.

- La revalución mexicana 1910-1940, Jus, México, 1991.

\section{- La Cristiada, México, Siglo XXI,} 1993,3 vols.

-Meyer, Lorenzo, "La etapa formativa del Estado mexicano contemporáneo (1928-1940)", Foro Internacional, vol. xvil, núm. 4, abril-junio de 1977, pp. 453-476.

- El conflicto social en los gobiernos del maximato. Historia de la revolución mexicana (19281934), Colmex, México, 1978, t. 13.

"La periodización de la historia política de México en el siglo Xx", Estudios Políticos, octubre-diciembre de 1979, pp. 183-194.

(coord.), "Introducción" a Revolución

y sistema. México entre 1910 y 1940, SEP, México, 1987.

,"El presidencialismo. Del populismo al neoliberalismo", Revista Mexicana de Sociología, vol. XI, núm. 2, abril-junio de 1993.

-Michaels, Albert, "El nacionalismo conservador mexicano", Historia Mexicana, vol. XVI, núm. 2, octubre-diciembre de 1966, pp. 213-238.
-Molinar Horcasitas, Juan, El tiempo de la legitimidad, Cal y Arena, México, 1991.

- "Escuelas de interpretación del sistema político", Revista Mexicana de Sociología, vol. XI, núm. 2, abril-junio de 1993, pp. 3-56.

-Monroy, H. Guadalupe, Política educatica de la revolución (1910-1940), SEP, México, 1985.

-Monsiváis, Carlos, "La aparición del subsuelo. Sobre la cultura de la revolución mexicana", Historias, núms. 8-9, enero-junio de 1985 , pp. 159-166.

-Mosk, Sanford, "La revolución industrial en México", Problemas Agricolas e Industriales de México, vol. II, núm. 2, abril junio de 1951.

-Ortiz Mena, Antonio, El desarrollo estabilizador: reflexiones sobre una época, FCE/COLMsX, México, 1998.

-Nava, Carmen, "Apuntes acerca de la historiografía de la revolución mexicana" en VIII Jornadas de Historia de Occidente, Centro de Estudios de la Revolución Mexicana "Lazáro Cárdenas del Río", México, 1986, pp. 43-74.

-Paz, Octavio, El laberinto de la soledad, $\mathrm{JCE}$, México, 2000.

-Portantiero, Juan Carlos, La producción de un orden. Ensayos sobre la democracia entre el Estado y la sociedad, Nueva Imagen, Buenos Aires, 1988.

-Potash', Robert, "Historiografía del México independiente", Historia Mexicana, vol. x, núm. 3, enero-marzo de 1961, pp. 361-412.

-Putnam Hilary, "La 'corroboración' de las teorías" en Ian Hacking (comp.), Revoluciones científicas, FCE, México, 1985, pp. 116-152.

-Raat, Dirk, "La revolución global de México", Historia Mexicana, vol. xxxII, núm. 3, enero-marzo de 1983, pp. 422-448.

-Reyna, José Luis, "Control político, estabilidad y desarrollo en México", Cuadernos del CES, Colmex, núm. 3, 1976.

,"México. El sistema y sus partidos: entre el autoritarismo y la democracia" en $\mathrm{L}$. Meyer y J. L. Reyna (coords.), Los sistemas políticos en América Latina, Siglo XXI, México, 1989. 
-Rico Moreno, Javier, Pasado y futuro en la bistoriografía de la revolución mexicana, CONACULTA/INAH/UAM-Azcapotzalco, México, 2000.

-Ross, Stanley R., "Aportación norteamericana a la historiografía de la revolución mexicana", Historia Mexicana, vol. x, núm. 2, octubre-diciembre de 1960, pp. 282-308.

—. "Historia política: la revolución mexicana", Historia Mexicana, vol. XV, núms. 23, octubre-diciembre de 1965, pp. 425-445. (ed.), ¿Ha muerto la revolución mexicana?, Premia, México, 1981.

-Salmerón Sanginés, Pedro y Pablo Serrano Álvarez, "El auge de la historiografía política regionalista en México, 1968-2000. Revisionismo y análisis político", Secuencia, núm. 57, septiembre-diciembre de 2003, pp. 185-200.

-Sartori, Giovanni, Elementos de teoría política, Ariel, Madrid, 1999.

-Segovia, Rafael, Lapidaria política, $\mathrm{FCE}$, México, 1996.

-Semo, Ilán, "El cardenismo revisado: la tercera vía y otras utopías inciertas", Revista Mexicana de Sociología, vol. Lx, núm. 2, abril-junio de 1993.

-Serrano Álvarez, Pablo, "Historiografía local y regional sobre la revolución mexicana. Estado actual y perspectivas", Sólo Historia, octubrediciembre de 2000 , pp. 4-8.

-Silva Herzog, Jesús, "La revolución mexicana en crisis", Cuadernos Americanos, vol. Xl, núm. 5, septiembre-octubre de 1943, pp. 32-55.

-Simpson, Eyler, "El ejido, única salida para México", Problemas Agricolas e Industriales de México, vol. IV, núm. 4, octubre-diciembre de 1952.

-Skocpol, Theda, Los estados y las revoluciones sociales. Un análisis comparativo de Francia, Rusia y Cbina, FCE, México, 1984.

-Tannenbaum, Frank, La paz por la revolución, Ercilla, Santiago, 1938.
The Mexican Agrarian Revolution, The Macmillan Company, Nueva York, 1929. , Mexico, The Struggle for Peace and

Bread, New York, Alfred A. Knopf, 1950.

-Tobler, Hans Werner, La resolución mexicana. Transformación social y cambio político, 1876-1940, Alianza Editorial, México, 1994.

-Torres Septién, Valentina, La educación privada en México 1903-1976, Colmex, México, 1997.

-Vasconcelos, José, Memorias II. El desastre. El proconsulado, FCE, México, 1993.

-Vernon, Raymond, El dilema del desarrollo económico, Diana, México, 1966.

-Villoro, Luis, "La cultura mexicana de 1910 a 1960 ", Historia Mexicana, vol. x, núm. 2, octubre-diciembre de 1960, pp. 196-219.

-Wences Reza, Rosalío, El morimiento estudiantil y los problemas nacionales, Nuestro Tiempo, México, 1971.

-Wilkie, James W., La revolución mexicana (1910-1976). Gasto federal y cambio social, ICE, México, 1987.

-Womack, John, "Mexican political historiography" en Investigaciones contemporáneas sobre bistoria de México: memorias de la tercera reunión de historiadores mexicanos y norteamericanor, Oaxtepec, Morelos, 4-7 de noviembre de 1969, unAm/ Colmex/Austin University of Texas, México, 1971.

, Zapata and the Mexican Revolution, Alfred A. Knopf, Nueva York, 1969.

- "La revolución mexicana, 19101920" en Leslie Bethel (ed.), Historia de América Latina, Crítica, Barcelona, 1992, vol. 9.

— y Jean Meyer, "Diálogos sobre historiografía de la revolución mexicana", Casa del Tiempo, núm. 3, noviembre de 1980, pp. 4-12. 